\title{
Presidential Amendment and Termination of Treaties: The Case of the Warsaw Convention
}

For more than thirty years the Warsaw Convention of $1929^{1}$ posed a major obstacle to recovery of damages beyond the treaty's specified limitation of $\$ 8,300$ by international air passengers who suffered death or personal injury. Finally, on November 15, 1965, the United States Ambassador to Poland delivered a diplomatic note denouncing the Warsaw Convention "solely because of dissatisfaction with the low limits of liability [for air carriers] provided in the Convention."'2 However, just one day prior to the effective date of the denunciation ${ }^{3}$ (May 15, 1966), the Department of State announced that it would withdraw denunciation and the United States would resume its commitments in matters relating to international civil aviation within the framework of the Warsaw Convention as altered by a "new plan."4 The Department of State disclosed that the note was withdrawn because most of the world's principal air carriers had agreed to conditions set forth by the Administration that would provide victims of air disasters on journeys to or from the United States with up to

1 Convention for the Unification of Certain Rules Relating to International Carriage by Air and Additional Protocol with Other Powers, Oct. 12, 1929, 49 Stat. 3000, T.S. No. 876 (1934) [hereinafter cited as the Warsaw Convention].

2 Department of State Notice of Denunciation of the Warsaw Convention, 53 DEP'T State Bull. 924 (1965), reprinted in 31 J. AIR L. \& Com. 303 (1965). Accompanying press releases are found in 53 DeP'T StATE Bull. 923 (1965), and 31 J. AIR L. \& CoMr. 303 (1965).

3 Article 39 of the Warsaw Convention provides for denunciation in the following terms: "(1) Any one of the High Contracting Parties may denounce this convention by a notification addressed to the Government of the Republic of Poland, which shall at once inform the Government of each of the High Contracting Parties. (2) Denunciation shall take effect six months after the notification of denunciation, and shall operate only as regards the party which shall have proceeded to denunciation."

The term "denunciation" as used throughout this comment does not mean repudiation of an international commitment, but merely unilateral withdrawal from a treaty in accordance with its own provisions. The word "termination" usually connotes withdrawal of one party from a bilateral treaty. See note 38 infra and accompanying text.

4 The note to the Polish Government dated May 14, 1966, on the withdrawal of the denunciation is reprinted in 32 J. AIR L. \& CoM. 248 (1966), 54 Dep't STAte Bull. 1033 (1966). See also Dep't of State, Press Release No. 110, May 13, 1966; Dep't of State Letter in 32 J. AIR L. \& CoM. 243-47 (1966). 
$\$ 75,000$ in damages without proof of carrier fault. ${ }^{5}$ At the time of this action, however, neither the efforts to denounce the Warsaw Convention nor the subsequent modifications promoted by the executive branch had been formally advised or consented to either by Congress as a whole or by the Senate. In fact, conditions similar to those imposed by the Administration had been previously rejected at the international conference tables and in Congress. ${ }^{6}$

Despite the broad powers already granted to the President to conduct this country's foreign relations, ${ }^{7}$ and the increasingly delicate interdependence of foreign and domestic affairs, ${ }^{8}$ serious constitutional questions are raised by the procedures through which the new arrangement was created. May the President now cancel or revise international obligations affecting private rights without legislative concurrence? To what extent is the President, acting alone, best suited to determine the character and binding effect of these obligations? Beginning with the events preceding the carrier liability agreement, this comment examines the legal bases for independent executive authority to terminate or modify treaties, and concludes that the law requires a joint effort between the executive and legislative branches. ${ }^{9}$ The Warsaw Conven-

5 The framework for an "interim arrangement" among carriers is set forth in Dep't of State, Press Release No. 110, May 13, 1966, and in Dep't of State document entitled "United States Government Action Concerning the Warsaw Convention," May 5, 1966, both reprinted in $32 \mathrm{~J}$. ArR L. \& CoM. 243-47 (1966).

- See notes 20-30 infra and accompanying text.

7 These powers, in the words of President Truman, "would have made Caesar or Genghis Khan or Napoleon bite his nails with envy." Rossirer, The AMerican PresiDENCY 30 (1960). Explains Hirschfield, The Powers of the Contemporary Presidency, 14 PARLIAMENTARY Affatrs 353 (1961): "In general terms the Presidency at the beginning of the 1960's is easily described: It is the focus of both the American governmental system and the free world coalition, an office of great authority and commensurate responsibility. Resting firmly on the twin supports of democratic election and the necessities of a critical era, it is now a permanently strong office, an institutionalized version of Lincoln, Wilson, Roosevelt, and Truman. And like the regimes from which it stems, the outstanding feature of the executive office today is power."

8 The distinction which Mr. Justice Sutherland attempted to draw between government's roles in respect to "foreign or external affairs and those in respect of domestic or internal affairs," United States v. Curtiss-Wright Export Corp., 299 U.S. 304, 315 (1936), has since undergone almost daily obliteration. Not only has the United States committed vast resources and manpower to furthering its relations abroad, but international complications have to a great extent shaped the policies pursued at home. "No one familiar with the New Orleans Mafia riots, the troubles of foreign corporations seeking state licenses, or more recently, Birmingham and segregation on Route 40 , can doubt the impact of state conduct on American foreign relations." Howard, Constitutional Limitation and American Foreign Policy, in Essays on The AMERICAN Constitution 159, at I64 (Dietze ed. 1964).

9 Beyond the scope of this comment is the continuing controversy whether the treatymaking clause has been made obsolete by another device, the "executive agreement," which may be concluded by the President's independent powers or with authority from 
tion changes were attained without this cooperation, and therefore indicate a disturbing shift in the constitutional balance of powers.

\section{The Warsaw Convention: Past and Present}

The Warsaw Convention is perhaps the most universally accepted commercial treaty ever framed. It has over ninety adherents who account for ninety-nine per cent of the total revenue from international air services, ${ }^{10}$ and is considered by many to be "the only widespread substantive achievement in the unification of private law by international agreement."11 But although it represents "the core of international civil aviation,"12 influencing domestic liability policies of member and non-member states alike, ${ }^{13}$ it has nevertheless found a less ready acceptance in the United States. ${ }^{14}$ Frequently attacked in the courts as

Congress. Power in the Chief Executive to bind the United States to such agreements was the subject of much debate during the Bricker Amendment controversy in the mid-1950s. See Bricker \& Webb, Treaty Law vs. Domestic Constitutional Law, 29 Notre Dame LAw 529 (1954); Perlman, On Amending the Treaty Power, 52 Colum. L. REv. 825 (1952). As to the subject matter presently considered exclusively reserved for the treaty power and not the executive agreement, see Byrd, TrEaties and Executive AgReEMENTS IN THE UNited States 132-35 (1960). The question of whether the treaty mechanism has become a constitutional anachronism is effectively debated by McDougal \& Lans, Treaties and Congressional-Executive or Presidential Agreements: Interchangeable Instruments of National Policy, 54 YALE L.J. 181 (1945) and Borchard, Treaties and Executive Agreements-A Reply, 54 YALE L.J. 616 (1945). The fact that countless vital obligations between the United States and foreign powers today exist in the form of ratified treaties preserves the justification for the present inquiry into the requisite authority to amend or terminate treaty obligations.

10 Reiber, Ratification of the Hague Protocol; Its Relation to the Uniform Intermational Air Carrier Liability Law Achieved by the Warsaw Convention, 23 J. AIr L. \& Com. 272, 279 (1956). Warsaw Convention adherents as of June 6, 1966, are listed in 3 Av. L. REP. I 27,053 (1966).

11 Lowenfeld \& Mendelsohn, The United States and the Warsaw Convention, 80 HARv. L. REv. 497, 513 (1967).

12 Ibid.

13 Many European and South American states, including the United Kingdom, France, Belgium, Luxemburg, Greece and Switzerland, Argentina, Brazil, Mexico, and Uruguay, have adopted the Warsaw Rules into their own liability laws. Sand, Air Carrier's Limitation of Air Passengers' Accident Compensation Under the Warsaw Convention, $28 \mathrm{~J}$. AIR L. \& CoM. 260, 264-65 (1962).

14 When the Convention terms were completed in 1929 by the major European aviation and governmental interests, United States representatives participated only as observers. Five years later, United States international air traffic was still limited to one airline flying to Cuba; but the President and his advisors optimistically concluded that future aviation and passenger interests could be best served by signing and adopting the treaty. See Report by Secretary of State Cordell Hull to President Franklin D. Roosevelt, Feb. 7, 1934, in S. ExEc. Doc. No. G, 73d Cong., 2d Sess. 3 (1934). On June 15, 1934, the Senate advised adherence, subject to the reservation under the "Additional Protocol," and the President proclaimed it as law on October 29, 1934. Comprehensive treatment of the Convention and its many subsequent developments has been given by 
cementing undesirable provisions into an otherwise progressively evolving domestic policy, the treaty has been upheld as constitutional on several counts. ${ }^{15}$ Assaults have centered primarily upon the treaty's limitation of carrier liability to 125,000 gold francs ${ }^{16}(\$ 8,291)$ unless the carrier "be proved guilty of "wilful misconduct"; 17 but despite benefits to passengers resulting from the presumption of carrier liability, ${ }^{18}$ this wrongful death limitation has generated continued controversy.

Opposition to the treaty intensified following the famous 1953 court decision limiting singer Jane Froman to a Warsaw award of $\$ 8,300$ despite actual damages in excess of one million dollars incurred in a 1943 Portugal landing accident. ${ }^{19}$ To encourage amendment of the treaty's

the following authorities: Drion, Lrmitation of Lxabilities in InTERnational Air LAw (1954); Calkins, Grand Canyon, Warsaw and the Hague Protocol, 23 J. AIR L. \& CoM. 253 (1956); Ereli, The Hague Protocol: An Abuse of Executive Discretion? 11 U.C.L.A.L. Rev. 358 (1964); Karlin, Warsaw, Hague, the 88th Congress and Limited Damages in International Air Crashes, 12 DE PAuL L. Rev. 59 (1963); Kreindler, The Denunciation of the Warsaw Convention, 31 J. AIR L. \& Com. 291 (1965); Lowenfeld \& Mendelsohn, supra note 11; Orr, The Warsaw Convention, 31 VA. L. REv. 423 (1945); Reiber, supra note 10; Sand, supra note 13.

15 It has been challenged in the courts as unconstitutionally interfering with Congress' right to control foreign commerce, Indemnity Ins. Co. of No. Am. v. Pan American Airways, Inc, 58 F. Supp. 338 (S.D.N.Y. 1944); Wyman v. Pan American Airways, Inc., 181 Misc. 963, 43 N.Y.S.2d 420, aff'd 267 App. Div. 947, 48 N.Y.S.2d 459 (1944); as depriving plaintiffs of their right to trial by jury for the determination of damages, Pierre v. Eastern Air Lines, I52 F. Supp. 486 (N.J. 1957); and as contravening state law, Da Costa v. Caribbean Int'l Airways, 4 Av. L. REP. If 17,792 (1955).

16 Warsaw Convention art. 22. Although the value of gold francs has fluctuated upward in the United States since the limitation was originally fixed, it has not kept pace with the heightening costs of living. Orr, The Rio Revision of the Warsaw Convention, $21 \mathrm{~J}$. AIR L. \& CoM. 174 (1954).

17 Warsaw Convention art. 25. "Wilful misconduct" in a term of art with varied constructions. See generally Acosta, Wilful Misconduct under the Warsaw Convention: Recent Trends and Developments, 19 U. MiAMI L. REv. 575 (1965); Kreindler, supra note 14, at 295; Strock, Warsaw Convention-Article 25- “Wilful Misconduct," 32 J. AIR L. \& Com. 291 (1966).

18 Warsaw Convention art. 17. This presumption of liability can be defeated only by proving that the carrier took "all necessary measures to avoid the damage" or that "it was impossible . . to take such measures." Id. at art. 20(1). Other benefits accruing to both carrier and passenger include a uniform body of substantive law providing available forums in which to bring suit, id. at art. 28; and for the handling of documents and shipping liability. It is said that no other business has its own international system of law laid down for the benefit not only of carriers and shippers but also of passengers. Testimony by Stuart G. Tipton, President of the Air Transport Association, Hearings on the Hague Protocol to the Warsaw Convention Before the Senate Committee on Foreign Relations, 89th Cong., lst Sess. Pt. 2, at 49 (1965) [hereinafter cited as 1965 Senate Hearings].

19 Froman v. Pan American Airways, 284 App. Div. 935, 135 N.Y.S.2d 619 (1954), leave to appeal denied, 308 N.Y. 1050, cert. denied, 349 U.S. 947 (1955); Ross v. Pan American Airways, 299 N.Y. 88, 85 N.E.2d 880 (1949). Congress in 1962 passed a special relief bill 
unrealistic limitations, the Eisenhower Administration called for an international conference in 1955 at The Hague, and there proposed to triple the Warsaw amount to $\$ 25,000$. The most that could be achieved, however, was a compromise at $\$ 16,000$, or twice the Warsaw limit, which the President signed in June 1956 as the Hague Protocol. ${ }^{20}$ It was not until July 1959 that the Protocol was submitted to the Senate for approval as an amendment to the Warsaw Convention; there it languished in committee until President Kennedy had it withdrawn in June 1961 for further study. ${ }^{21}$ On August 7, 1964, the Secretary of State resubmitted the Hague Protocol to the Senate Foreign Relations Committee with a recommendation that it be ratified only after it was implemented by legislation imposing upon American flag-carriers automatic, compulsory trip insurance in the amount of $\$ 50,000 .{ }^{22}$

Committees in both houses reported resistance to the Government's proposal for strict-liability insurance legislation, and even to the perpetuation of limited liability through the Hague Protocol; some witnesses suggested that the United States withdraw from the WarsawHague system altogether. ${ }^{23}$ Denunciation, however, would admit defeat

for Miss Froman and the other injured USO entertainers aboard the ill-fated airliner, in the sum of $\$ 20,000$ each as "full and final settlement of the respective claims . . . against the United States." Priv. L. No. 87-684, 76 Stat. 1411 (1962).

20 Protocol Amending the Convention for the Unification of Certain Rules Relating to International Carriage by Air (The Hague Protocol), S. ExEc. Doc. No. H, 86th Cong., Ist Sess. 5 (1959); 3 Av. L. REP. I 27,101 (1966). At The Hague, the United States' proposal was opposed by a majority of states which had determined two years previously in Rio de Janeiro that a 50 per cent increase was adequate. Lowenfeld \& Mendelsohn, supra note 11, at 504-06. It was only after this country agreed to proscribe several loopholes which would allow recovery beyond the agreed limitation that the other nations broke the impasse with a compromise. See generally Lowenfeld \& Mendelsohn, supra note 11, at 505-09; Kreindler, supra note 10, at 295-97. The Administration was generally satisfied that nothing more could be achieved at the international level. See Letter of Comment, September 12, 1956, in S. Exec. Doc. No. H, 86th Cong., 1st Sess. 21 (1959) [hereinafter cited as S. ExEc. Doc. No. H].

21 See generally Kreindler, supra note 14, at 297-98; Lowenfeld \& Mendelsohn, supra note 11 , at 533-38.

22 An executive interagency committee called the Interagency Group on International Aviation (IGIA), composed of the Federal Aviation Agency, the Civil Aeronautics Board, and the executive Departments of State, Commerce, Defense, Justice and Labor, had studied suggestions that the 1938 Federal Aviation Act be amended to require United States flag-carriers to accept liability limitations of $\$ 50,000$ on a proof-of-fault basis, as well as a requirement of automatic, compulsory insurance in the amount of $\$ 25,000$, or twice the Hague ceiling, before reaching a compromise plan which combined the $\$ 50,000$ proposal with absolute liability. See authorities cited note 21 supra; 1965 Senate Hearings 118-20.

23 Initial opposition to the insurance legislation was registered by the airlines and insurance industries, followed by various trial lawyers' association and even the FBI. Opposition was based on the strict liability provisions, which allegedly provided incentive 
of a major administration commitment. ${ }^{24}$ As a final alternative to political embarrassment, the President through the State Department proposed that, pending another international attempt to amend the Warsaw treaty by conference scheduled for February 1966 in Montreal, all United States carriers voluntarily waive their limits upward to $\$ 100,000$ by filing new tariffs with the Civil Aeronautics Board. ${ }^{25}$ When it became clear that the airline companies would not agree to more than $\$ 50,000,26$ and that the Hague-insurance package would be

to sabotage airplanes for insurance, thereby making detection by purchase of private coverage more difficult. Most witnesses encouraged a return to common law principles of full compensatory damages upon proof of fault. Many private attorneys, professors, university deans, and lawyers' associations went on record favoring United States withdrawal from the Warsaw System. 1965 Senate Hearings 26-28; see Lowenfeld \& Mendelsohn, supra note 11, at 538-46. The Foreign Relations Committee seemed uncertain about the manner of withdrawing:

Senator CARLSON. Mr. Speiser, you suggest that we denounce ... the Warsaw Convention.

Mr. SPEISER. Yes.

Senator Garison. That gets to be an executive act, I think, and only the President can do that, isn't that correct?

Mr. SPEISER. I have discussed this with the State Department and apparently the United States has denounced treaties in two ways, either by the President alone and [sic] the Senate.

Senator CARISON. I would assume that the Senate, of course, could advise the President by resolution. We probably could cut off funds and we probably have other methods, but personally, I would feel that it would be an executive act.

1965 Senate Hearings 62. See also the questioning of Mr. Buschmann by Senator Sparkman, id. at 42.

The primary result of the committee hearings was a report dated June 29 , 1965, recommending ratification of the protocol unless the complementary insurance program was "not enacted within a reasonable time (i.e., prior to the adjournment of the 89th Congress)," in which case "the Department of State should take immediate steps to denounce the Warsaw Convention and The Hague Protocol." Dep't of State Letter, supra note 5, at 244. See 1965 Senate Hearings 6-7; Lowenfeld \& Mendelsohn, supra note 11, at 544-46.

24 " [I] $\mathrm{t}$ was felt within the Government that the United States had been the moving party at The Hague, that a substantial number of other countries had followed the American lead, and that it would be somehow improper for the United States now to abandon its own creation." Lowenfeld \& Mendelsohn, supra note 11, at 532-33, 546-47; Kreindler, supra note 14, at 300-01.

25 Dep't of State Letter, supra note 5, at 244; Lowenfeld \& Mendelsohn, supra note 11 , at 547-50. See note 123 infra and accompanying text.

26 The airlines responded with a documented counter-proposal of $\$ 50,000$ maximum drawn from information regarding recent settlements and injury verdicts, economic characteristics of United States passengers, indemnity practices of Government and industry, private bills passed by Congress for special compensation, and liability limitations established by state and federal statutes, encompassing the years 1950 to 1964 . Kreindler, supra note 14, at 301. Lowenfeld \& Mendelsohn, supra note 11, at 547-58. International cooperation in support of a $\$ 50,000$ limitation was obtained among many nations that had previously refused to go beyond $\$ 16,000$ at The Hague, but signed a mail petition circulated by the IATA for the purpose of preventing United States denunciation of the Warsaw treaty. See Flight International, Sept. 23, 1965, p. 538; Lowenfeld \& Mendelsohn, supra note 11, at 549. 
rejected by Congress, ${ }^{27}$ the Administration on November 15, 1965 formally denounced the treaty by notice to take effect six months after delivery. ${ }^{28}$

The Department of State disclosed that denunciation was not, however, unconditional. Rather, it would be rescinded if (1) the results of the Montreal conference indicated reasonable international support for the new Warsaw limit of $\$ 100,000$ per passenger, and (2) the principal world carriers agreed to a provisional limit of $\$ 75,000$ until a higher limitation could be implemented. ${ }^{29}$ At Montreal, the Government proposal received virtually no support, and the conference ended inconclusively. But Andreas F. Lowenfeld and Allan I. Mendelsohn, two United States delegates to the Montreal conference, thereafter noted: " $[T]$ he feeling was beginning to spread that if the United States withdrew from Warsaw the whole treaty would unravel ..." and that many countries appeared willing to make high concessions to prevent withdrawal..$^{30}$

Capitalizing on this feeling, the Administration on March 7, 1966, suddenly altered the terms for a "satisfactory interim arrangement" by designating forty-three United States and foreign flag-carriers who must accept a new limit of $\$ 75,000$ on an absolute liability basis in order to avoid denunciation. ${ }^{31}$ By the eve of the May 15 deadline, all but three of the specified airlines had come to terms; ${ }^{32}$ the Department of State

27 Chairman Mike Monroney of the Senate Commerce Subcommittee on Aviation advised the President that the strict liability legislation lacked support, and that without a better alternative, the protocol would also fail of approval. Kreindler, supra note 14, at 300-01. During the summer of 1965, Congressman Wolf introduced a resolution asking Congress to go on record in favor of denunciation, which four Senators supported in a speech on the Senate floor. Kreindler, supra note 14, at 300-01; Lowenfeld \& Mendelsohn, supra note 11 , at $546-49$.

28 See note 3 supra.

29 Dep't of State Letter, supra note 5, at 245.

30 Lowenfeld \& Mendelsohn, supra note 11, at 590. See also Lowenfeld \& Mendelsohn at 569,586-87. Of the fifty-nine states and 121 carriers in attendance at Montreal, a few preferred the old Hague limits of $\$ 16,600$. But most were willing to go as high as $\$ 33,000$ or $\$ 50,000$ and some even to $\$ 75,000$ to avert United States denunciation of the treaty. A variety of plans presented at the conference is discussed in Lowenfeld \& Mendelsohn, supra note 11, at 563-75. The concern over United States withdrawal is understandable in view of the fact that this country's airlines fly more international air miles than all foreign carriers combined. S. ExEc. Doc. No. F 22; Ereli, supra note 14, at 362.

31 The reappearance and subsequent adoption by the carriers of strict liability despite its defeat at Montreal and the historic opposition by the United States to that principle of liability is carefully described by Lowenfeld \& Mendelsohn, supra note 11, at 558-61, 587-96.

32 The three holdouts were American carriers-United, Delta, and National-which "announced that they would agree to waive their liability limits in Warsaw cases to $\$ 75,000$ per passenger, though they would not agree to absolute liability." Id. at 595. Even these carriers have now signed the Montreal agreement. 3 Av. L. REP. If 27,130 (1966). 
was able dramatically to retract its notice of denunciation; ${ }^{33}$ and the revised but still viable Warsaw Convention continued in force in the United States.

\section{The Power of Treaty Termination}

The entire Warsaw-Hague-Montreal sequence illustrates that on occasion the power to break treaties can create new policies far more quickly than the power to make treaties. Lowenfeld and Mendelsohn concluded that, primarily through skillful utilization of that power, "it came about that almost overnight, and without normal constitutional and legislative processes, the character of a major international treaty changed completely...."34 This executive fait accompli resulted in implementing terms even greater than had been rejected by the treaty members at The Hague and Montreal, by Congress, and by the carriers themselves. It has been suggested that even though the President thereafter cancelled the denunciation, he may again threaten to withdraw from the Convention if the interim arrangement does not soon lead to "a multilateral replacement treaty for the Warsaw-Hague combination," 35 In such event, a unique opportunity would be presented to litigate the issue whether the President alone may constitutionally terminate private rights established by treaty, since the executive

33 The question whether a state could withdraw an instrument of denunciation after it had been deposited is raised by Sincoff, Absolute Liability and Increased Damages in International Aviation Accidents, 52 A.B.A.J. 1122, 1124 (1966), who asserts that the United States is no longer a party to the Warsaw Convention, since only denunciation and not withdrawal of that denunciation was authorized by the treaty. But the problem is seemingly resolved by at least seven precedents in which the President withdrew notice of termination prior to the effective date. Concerning treaties with Great Britain, see H.R. Doc. No. 471, 56th Cong., Ist Sess. 28-34 (1856); Norway (1919), see 1 ForeIGN ReL. U.S. 47-52 (1934); Spain (1919), see 1 id. at 54-57 (1934); Italy (1917), see 1 id. at 18-26 (1926); Greece (1920), see 2 id. at 710-15 (1936); Estonia (1935), see 2 id. at 187-88 (1952), (and 1936), see 2 id. at 66-69 (1954); The International Whaling Convention, 40 DEP'T State Buld. 110, 144, 332 (1959), see 41 id. at 101 (1959), 46 id. at 154, 890, 1041 (1962). These precedents are cited in Crandald, Treaties: Their Making and Enforcenent 462.63 (2d ed. 1916); Hackworth, Digest of International Law 314-16 (1943); McCuure, International Executive Agreements 17 (1941); Levitan, Executive Agreements: A Study of the Executive in the Control of the Foreign Relations of the United States, 35 ILr. L. REv. 365, 377 (1940); Lowenfeld \& Mendelsohn, supra note 11, at 550 n.177. Significantly, a joint resolution sponsored by twenty-nine Senators directing the President not to withdraw the notice of denunciation of the Warsaw Convention was introduced in May 1966 and is currently pending before the Foreign Relations Committee. Lowenfeld \& Mendelsohn, supra note 11, at 594; 112 Conc. REc. 9087 (daily ed. May 3, 1966).

34 Lowenfeld \& Mendelsohn, supra note 11, at 601. Throughout their discussion of the "series of sometimes complicated, always controversial, and often misunderstood events," ibid., the authors seem to contend that the new arrangement could not have been imposed without the use of this effective policy-enforcing tool.

35 Riggs, Termination of Treaties by the Executive Without Congressional Approval: The Case of the Warsaw Convention, 32 J. AIR L. \& Cos. 526, 527 (1966). 
branch has seldom terminated self-executing treaties which directly affect individual parties and since the question has never been directly met by an American court. ${ }^{36}$

Most treaties relate merely to external governmental relations between countries. But Chief Justice Marshall explained that certain selfexecuting treaties create, in addition, an internal body of law governing rights between private parties:

A treaty is in its nature a contract between two nations, not a legislative act. It does not generally effect, of itself, the object to be accomplished ... but is carried into execution by the sovereign power of the respective parties to the instrument.

In the United States, a different principle is established. Our Constitution declares a treaty to be the law of the land. It is, consequently, to be regarded in courts of justice as equivalent to an act of the legislature, whenever it operates of itself without the aid of any legislative provision. ${ }^{37}$

Insofar as a treaty is an international contract, it may be terminated in several ways: ${ }^{38}$ (1) It may expire ipso facto because the period for which the treaty was entered into has elapsed; because its provisions are since fulfilled; because the performance becomes impossible; because of war; or because the subject matter has been extinguished. (2) It may be superceded by a new treaty covering the same subject matter, or by one wholly inconsistent with the earlier treaty. (3) It may be rescinded by mutual consent. (4) Unilateral notice of denunciation may be given because the other party to the treaty has breached its terms; and treaties like the Warsaw Convention may be terminated by notice as specified by its own terms. When a treaty is terminated by

$36 I d$. at 528. However, many cases dealing with closely related issues are cited in note 58 infra, and others are discussed hereinafter.

37 Foster v. Neilsen, 27 U.S. (2 Pet.) 253, 314 (1829). Marshall's explanation has been frequently repeated, e.g., Terlinden v. Ames, 184 U.S. 270, 288 (1902); Rhode Island v. Massachusetts, 37 U.S. (12 Pet.) 657, 747 (1838); United States v. Arredondo, 31 U.S. (6 Pet.) 691, 735 (1832).

U.S. Const. art. VI, \& 2 provides: "This Constitution, and the Laws of the United States which shall be made in Pursuance thereof; and all Treaties made, or which shall be made, under the authority of the United States, shall be the Supreme Law of the Land; and the Judges of every State shall be bound thereby, anything in the Constitution or Laws of any State to the contrary notwithstanding." On the internal binding effect of treaties, see United States v. Belmont, 30I U.S. 324, 331-32 (1937); Asakura v. Seattle, 265 U.S. 332 (1924); Missouri v. Holland, 252 U.S. 416 (1920).

38 See generally 5 HAckwORTH, op. cit. supra note 33, at 297-98; 5 MOORE, DigesT OF InTERnational LAW 319 (1902); Riesenfeld, The Power of Congress and the President in International Relations: Three Recent Supreme Court Decisions, 25 CaLIF. L. REv. 643 (1937). 
notice, it is to local, not international, law that the parties must look to derive their source of authority. ${ }^{39}$

In the United States, this task is made difficult by the fact that the Constitution apportions the powers to control foreign affairs between the President, Congress, and the Senate. It expressly locates the treatymaking agency. But as to the manner of termination, it is strangely silent. The Executive is granted the power to make treaties "by and with the advise and consent of the Senate"; ${ }^{40}$ but because a treaty becomes the "supreme law of the land,"41 it cannot bind the United States internally or externally until "two-thirds of the Senators present concur." 42 Congress, on the other hand, has exclusive power to enact all legislation, ${ }^{43}$ "to pay the debts," 44 and "to regulate commerce with foreign nations." 45 Thus, there exists language in the Constitution which could be construed as placing the power to terminate international commercial treaties in all of the three bodies. ${ }^{40}$ Authorities are split as to which should prevail, some arguing that the President acting alone may terminate a treaty in toto, ${ }^{47}$ while others contend that termination requires congressional or senatorial concurrence to have both international and internal effect. ${ }^{48}$

History reveals only that, in matters of treaty terminations, none of the organs has emerged with a final or decisive voice of authority. Green H. Hackworth, now United States representative to the Court of International Justice, summarized the state of affairs while Legal Advisor of the Department of State:

The question as to the authority of the Executive to termi-

$39 \mathrm{Id}$. at 656-58. At the threshold is the problem whether the power of termination exists at the federal level or remains with the states under the tenth amendment. "It is evidently clear, however, that by a reasonable construction some department of the federal government must possess the power, and the question is only where does it rest." Id. at 656 .

40 U.S. CoNsT. art. II, § 2.

41 U.S. Consr. art. VI.

42 U.S. ConsT. art. I1, § 2. Regarding the ability to bind the United States externally, see authorities cited note 112 infra.

43 U.S. CONST. art. I, § I.

44 U.S. CoNST. art. I, § 8.

45 U.S. Const. art. I, \& 8.

46 Professor Edward S. Corwin has suggested that the dilemma presented by this concurrent alignment of powers offers "an invitation to struggle": "[W]hich of these organs shall have the decisive and final voice in determining the course of the American nation in international affairs is left for events to resolve." Corwin, The President: Office AND POWERS 171 (4th ed. 1957).

475 HACKWORTH, op. cit. supra note 33, at 328; McCluRE, op. cit. supra note 33, at 17-20, 306-07.

48 Riggs, supra note 35, at 533-34; cf. Crandall, op. cit. supra note 33, at 460, 465; 1 Willoughiy, The Constitutional Law of the United States 584-85 (1929). 
nate treaties independently of the Congress or of the Senate is in a somewhat confused state . ... In some cases treaties have been terminated by the President pursuant to action by Congress. In other cases action has been taken by the President pursuant to resolutions of the Senate alone. In still others the initiative has been taken by the President. In some cases his action was afterwards notified to the Senate or to both Houses of Congress and approved, in other cases it was not referred to either House. No settled rule or procedure has been followed. ${ }^{49}$

It is worth noting that, through usage, the President has emerged with superior authority regarding functions closely related to the termination power. First, notwithstanding the constitutional requirement that the Senate participate in preliminary negotiations of treaties, which the President shall make "by and with the advise and consent of the Senate," a steady stream of presidential practice has eroded this premise. George Washington in August 1789 took treaty proposals to the Senate chambers "to advise with them on the terms of the treaty to be negotiated with the Southern Indians." "50 Tradition relates that, due to insulting delays, he strode away from the hill in disgust, vowing that he "would be damned if he would ever go there again."51 Though he did not return, he continued to consult the Senate "at a discrete distance" as a council on treaty details. Successors abandoned even this practice, preferring to counsel only with select congressmen in whom they could confide.52 The Supreme Court supported the submission of treaties to the full Senate only after the Executive had negotiated them when it said: "[The President] makes treaties with the advise and consent of the Senate; but he alone negotiates. Into the field of negotiation the Senate cannot intrude; and Congress itself is powerless to invade." 53

Another power conceded to the President is that of communication with foreign governments, a right early claimed by Congress. ${ }^{54}$ The Court has asserted that: "The President is the sole organ of the nation in its external relations, and its sole representative with foreign nations." ${ }^{55}$ In 1909, Congress codified this diplomatic prerogative into

495 HACKWORTH, op. cit. supra note 33 , at 330.

50 McCrure, op. cit. supra note 33, at 239-40; 1 Richardoson, Messages and Papers of the Presidents 61 (1897).

511 WilloughBY, op. cit. supra note 48, at 521.

52 See ibid.; MCCLuRE, op. cit. supra note 33, at 239-40.

53 United States v. Curtiss-Wright Export Corp., 299 U.S. 304, 319 (1936) (dictum).

54 See notes 97-101 infra and accompanying text.

55 First declared by John Marshall in the House of Representatives in 1800, 10 Annars of CoNG. $613(1800)$, this maxim has been repeated often by the Supreme Court. United 
the Logan Act, unofficially entitled "An Act to Prevent the Usurpation of Executive Functions." ${ }^{\text {"56 }}$ But though the President is securely installed as the nation's mediary in its dealings with other countries, this position does not compel the conclusion that he alone is responsible for determining the policies which are later conveyed to foreign parties: "That is to say, while the President alone may address foreign governments and be addressed by them, yet in fulfilling these functions he is, or at least may be, the mouthpiece of a power of decision that resides elsewhere." 57 Thus, it may be that the authority to decide treaty terminations must rest or be shared with a body outside the Presidency.

\section{A. Independent Terminations by the Executive}

Just as the wide diversity of non-judicial precedents affords no conclusive procedure for terminating treaties, judicial decisions have failed to locate a precise residence for that authority. But though the courts have declined to decide whether the President may not terminate without legislative action, bypassing the issue as a "political question," 58 they have laid guidelines as to when he may act indepen-

States v. Curtiss-Wright Export Corp., 299 U.S. 304, 319 (1936); Charlton v. Kelly, 229 U.S. 447 (1913); Jones v. United States, 137 U.S. 202, 212 (1890); Williams v. Suffolk Ins. Co., 38 U.S. (13 Pet.) 415, 420 (1839); Foster v. Neilson, 27 U.S. (2 Pet.) 253, 314 (1829). See, e.g., Levitan, supra note 33 , at 372-73.

5618 U.S.C. \& 953 (1965); see CoRwIN, op. cit. supra note 46, at 183.

57 CoRWIN, op. cit. supra note 46, at 178 . The so-called "mouthpiece theory" stemmed from remarks made by James Madison during the controversy over Washington's 1793 Proclamation of Neutrality: "[Treaties] have sometimes the effect of changing not only the external laws of the society, but operate also on the internal code, which is purely municipal, and to which the legislative authority of the country is of itself competent and complete.

"From this view of the subject it must be evident that, although the executive may be a convenient organ of preliminary communications with foreign governments, on the subjects of treaty or war, and the proper agent for carrying into execution the final determinations of the competent authority, yet it can have no pretensions from the nature of the powers in question compared with the nature of the executive trust, to that essential agency which gives validity to such determinations." Roche \& LevY, THE Presidency 12 (1964); Thomas, American Neutrality in 1793, at 59 (1931). For further discussion of the theory see CoRwin, op. cit. supra note 46, at 184; Fairman, Competence to Bind the State to an International Engagement, 30 AM. J. INT'L L. 439, 441 (1936).

58 Typical of the issues related to foreign affairs which have been bypassed by the courts through the "political question" doctrine are: "whether a treaty with a foreign sovereign had been violated by him, whether a particular stipulation of a treaty had been voluntarily withdrawn by one party so as to no longer be obligatory upon the other, and whether the views and acts of a foreign sovereign, manifested through his representatives, had given just occasion to the political departments of our government to withhold the execution of such promise ...." The Chinese Exclusion Case, 130 U.S. 581, 600-02 (1889). Also, whether "a state is in a position to perform its treaty obligations following a war," Clark v. Allen, 331 U.S. 503, 514 (1947); whether a foreign country had properly ratified a treaty with the United States, Doe v. Braden, 57 U.S. (16 How.) 635, 656 (1853); and whether a treaty 
dently. In Van der Weyde v. Ocean Transport Co., ${ }^{59}$ the Court avoided deciding whether the Executive had authority "in the absence of congressional action, or of action by the treaty-making power, to denounce a treaty of the United States." 60 But it upheld the validity of executive termination of certain provisions of a treaty with Norway that the President considered to be in conflict with the 1915 Seaman's Act, even though Congress had not specifically advised him to terminate those particular provisions:

[I]t was incumbent upon the President, charged with the conduct [of] negotiations with foreign governments and also with the duty to take care that the laws of the United States are faithfully executed, to reach a conclusion as to the inconsistency between the provisions of the treaty and the provisions of the new law. ${ }^{61}$

Since the President cannot enforce two equally valid laws which are in conflict, he is compelled to select that which most reflects the current will of Congress. Accordingly, the very duty to execute the laws becomes at times "an authorization to dispense with the law." 62 By this rationale, independent denunciation of several treaties by executive notice alone may be justified. In addition to some twenty-five treaties affected by the 1915 Seaman's Act, $^{63}$ the 1871 commercial treaty with Italy was also terminated by executive action because President Roosevelt found that it tended to defeat the purposes of the 1934 Trade Agreements Act. ${ }^{64}$ Similarly, the United States withdrew from the 1927 Tariff Convention by presidential notice because it

remains effective after the other party has been merged into a new empire, Terlinden $v$. Ames, 184 U.S. 270, 288 (1902), are issues similarly circumvented. But the courts have recently increased their jurisdiction over foreign affairs to include such questions as the power of the President to enter into binding "executive agreements" without congressional consent, United States v. Pink, 315 U.S. 203 (1941); United States v. Belmont, 301 U.S. 324 (1937); to bring civilians under foreign military jurisdiction, Reid v. Covert 354 U.S. 1 (1957); to regulate foreign commerce or contravene acts of Congress by executive agreement, United States v. Guy W. Capps, Inc., 204 F.2d 655, 660 (4th Cir. 1953), aff'd on other grounds, 348 U.S. 296 (1955); and the power of Congress to abrogate treaties by subsequent inconsistent legislation, see cases cited note 103 infra. The Court in Baker v. Carr, 369 U.S. 186, 211 (1962) (dicta) stated: "[I]t is error to suppose that every case or controversy which touches foreign relations lies beyond judicial cognizance." See generally Scharpf, Judicial Review and the Political Question: $A$ Functional Analysis, 75 YALE L.J. 517, 542 (1966).

59297 U.S. 114 (1936).

$60 \mathrm{Id}$. at 117.

$61 \mathrm{Id}$. at 118 (emphasis added). See Riesenfeld, supra note 38, at 647-48.

62 CoRwin, op. cit. supra note 46 , at 122.

63 See 5 HACKWORTH, op. cit. supra note 33, at 309-12; MCCuURE, op. cit. supra note 33, at 23.

645 HACKWORTH, op. cit. supra note 33, at 330. 
stood in the way of possible restrictive action authorized by the National Industrial Recovery Act of 1933. ${ }^{65}$ More recently, President Truman terminated treaties with Poland and Hungary in response to the Trade Agreements Extension Act of 1951, which removed trade concessions for countries in the communist bloc. ${ }^{.6}$

Another consequence of the duty to execute the laws faithfully is the need to evaluate the continuing vitality of existing laws. While interpreting treaties preparatory to enforcing them, the President may discover that some have been breached by the other parties, ${ }^{07}$ or that they have expired because the terms are fulfilled or are impossible of performance. ${ }^{68}$ In Charlton v. Kelly, ${ }^{69}$ the Court recognized the President's right to terminate or extend a treaty violated by another party. There, the executive branch chose to waive the right to free the United States from the 1884 extradition treaty with Italy after that country refused to deliver up its citizens as agreed. With the 1931 extradition treaty with Greece, however, the President exercised the option by threatening to terminate because of Greece's refusal to extradite Samuel Insull, a utilities magnate accused of fraud. Following an understanding between the countries as to future interpretations of the treaty, the denunciation was withdrawn and the treaty remains in force today. ${ }^{70}$

65 See MCCLURE, op. cit. supra note 33 , at 18.

60 See Nelson, The Termination of Treaties and Executive Agreements by the United States: Theory and Practice, 42 MrNn. L. REv. 879, 882 (1958).

07 In 1815, President Madison's Secretary of State, James Monroe, notified the Netherlands that the Treaty of 1782 and other compacts had been terminated "by causes proceeding from the state of Europe for some time past." 2 FoREIGN REL. U.S. 722 (1873); McDougal \& Lans, supra note 9, at 336 n.127. President Grant in 1876 asserted in a message to Congress that, even in the absence of congressional action, he had power to decline to enforce a treaty which he thought had been abrogated by the other party. The operation of the treaty was subsequently suspended for six months. $I d$. at 336 n.128; 7 RICHARDson, op. cit. supra note 50 , at $371-73,414-16$.

68 The President suspended the International Loadline Convention of July 5, 1930, 47 Stat. 2228, T.S. No. 858 (1931), in reliance on the doctrine of rebus sic stantibus (fundamental changes in the state of facts and conditions upon which the treaty was based create the impossibility of one party's performance). The action was subsequently attacked as relying in fact "upon some vague and slippery doctrine of state necessity." Briggs, The Attorney General Invokes Rebus Sic Stantibus, 36 AM. J. INT'L L. 89, 94 (1942). The theory of rebus sic stantibus was briefly mentioned in Terlinden v. Ames, 184 U.S. 270 headn.4 (1902), where the President continued to recognize a treaty with Prussia even after that country was merged into the German Empire: "As the German Government officially recognized the treaty of 16 June 1852 as still in force, and not terminated because of impossibility of performance, and the executive department accepted that view and proceeded accordingly, it is not for the courts to question the correctness of that conclusion."

69229 U.S. 447 (1913).

70 See 5 HAckwortH, op. cit. supra note 33, at 315; MCCLURE, op. cit. supra note 33, at 
Acts of war toward allied nations led to Roosevelt's denunciation of the 1911 commercial treaty with Japan in 1939, even while a joint resolution was pending in both Houses of Congress to the same effect. The Washington Post called this action proof of the existence of the "very great latitude possessed by the Executive in the field of foreign policy," 71 and the Department of State rationalized the President's act under a nebulous power which "inheres in the President of the United States in his capacity as Chief Executive of a sovereign state."72 Such sweeping justifications were hardly necessary in this instance, however, since the President merely exercised his power to discard a treaty which he considered to have been invalidated by the other party's breach.

Until the Warsaw Convention episode in 1965, by far the majority of all presidential terminations could be justified by the duty to execute the laws faithfully. However, it is clear that this authorization does not extend to treaties that have not been violated, or placed in conflict with more recent federal legislation, and which are possible of performance. Because the Warsaw Convention is fully consistent with all acts of Congress and has at no time been breached by member nations, the President's recent action cannot be justified by this constitutional rationale.

It has been argued that termination of treaties, like the removal of executive officials, ${ }^{73}$ is essentially a negative act with no legislative im-

18. The United States and Greece concluded an interpretive protocol which was "not regarded as necessary to submit to the Senate since it did not change the treaty as interpreted by the United States." 5 HAckworth, supra at 315.

71 Washington Post, July 28, 1939, p. 4, col. 2, cited in MCCLuRE, op. cit. supra note 33 , at $19-20$.

725 HACKWORTH, op. cit. supra note 33, at 331.

73 In Myers v. United States, 272 U.S. 52 (1926), the Court affirmed the President's right to dismiss a postmaster before the expiration of his term, stressing the Executive's need of some "reserve power of removal" as a disciplinary influence over his subordinates. Justices Holmes, Brandeis, and McReynolds viewed the decision as a dangerous extension of executive powers, Brandeis concluding his dissent thus: "In America, as in England, the conviction prevailed then [at the time of the framing of the Constitution] that the People must look to representative assemblies for the protection of their liberties. And protection of the individual, even if he be an official, from the arbitrary or capricious exercise of power was then believed to be an essential of free government." Id. at 294-95. Nelson, supra note 66, at $883-88$, suggests that since the Constitution is silent as to both the power to terminate treaties and to remove officials, the Myers rationale should control the termination situation. But nine years after Myers, the Court narrowed its rationale in Humphrey's Executor v. United States, 295 U.S. 602 (1935), to include only "purely executive officers," and not members of quasi-legislative agencies whom the President has no exclusive power to remove. Insofar as a treaty is quasi-legislative, the Myers analogy is hardly controlling. But even more, the need to remove subordinate officers through whom the President must execute the laws for disciplinary purposes seems a tortured comparison to the cancellation of neutral, non-partisan laws themselves. 
plications and thus may be performed by the President when faced with constitutional silence. ${ }^{74}$ But one authority has rightly pointed out that cancellation of a treaty like the Warsaw Convention, which governs rights and liabilities between private persons, cannot be accomplished in vacuo:

Treaties, together with the Constitution and federal legislation, are at the top of the hierarchy of statutes establishing American law. Terminating a treaty of this sort automatically causes the applicable law in most cases to become that of the various states. In any case, some substitute local law moves in immediately to fill the void. The decision to terminate a legislative treaty, involving as it does the exchange of one body of law for another, is principally for the legislature, although the interests of the Executive in the conduct of foreign relations may be indirectly involved..$^{75}$

Throughout American constitutional history considerable attention has been devoted to erecting a theory under which the President is endowed with certain delicate, plenary, and exclusive powers to act unrestrained in the realm of foreign affairs unless expressly forbidden by the Constitution. During the dispute centering around Washington's proclamation of neutrality in 1793, Hamilton found authority in the article II grant of executive powers whereby the President received all executive authority of which the Government is capable, subject only to the exceptions expressed in the instrument. ${ }^{76}$ A corollary proposition was expounded by way of dicta by Mr. Justice Sutherland, in United States v. Curtiss-Wright Export Co., ${ }^{77}$ to the effect that all foreign affairs powers composing the royal prerogative of George III devolved directly upon the federal government and thus could be exercised by the President as "attributes of sovereignty."78 President

74 Nelson, supra note 66 , at 887-88.

75 Riggs, supra note 35 , at 533.

76 See Thomas, op. cit. supra note 57, at 55-56; Roche \& LevY, op. cit. supra note 57, at 10-11.

77299 U.S. 304, 315-19 (1936).

78 The extent to which text writers have quoted or paraphrased Sutherland's dicta without question is treated in BXRD, Treaties and EXEcutrve AGREEMENTS IN THE UNITED STATEs 91-96 (1960), together with opposing views of writers who have more carefully examined the origins of the Sutherland theory and the sovereign nature of the original colonies. The approach now taken by many modern commentators is exemplified by Mathews, The Constitutional Power of the President to Conclude International Agreements, 64 YALE L.J. 345, 348 (1955): "Theories of 'inherent powers' and of a mystic transmigration of the national foreign affairs power from Crown to Federal Government, supported by the rationalization that 'sovereignty is never held in suspense,' appear unduly metaphysical today." 
Truman was apparently referring to these concepts when he flatly declared: "I make American foreign policy."79 And, in the opinion of Woodrow Wilson: "One of the greatest of the President's powers is ... his control, which is very absolute, of the foreign relations of the nation. The initiative in foreign affairs which the President possesses without any restrictions whatever, is virtually the power to control them absolutely." 80

The Youngstown steel seizure case ${ }^{81}$ in 1952 gave the Supreme Court an opportunity to review the "executive grant" and "inherent powers" theories when the President without statutory authority ordered the Secretary of Commerce to seize steel mills during the Korean conflict. A majority of the court found that the President could not do so without specific authority from Congress or the Constitution. In concurring, Mr. Justice Jackson referred to the "Article II grant of power" theory: "I cannot accept the view that this clause is a grant in bulk of all conceivable executive power but regard it as an allocation to the presidential office of the generic powers thereafter stated." $82 \mathrm{He}$ also addressed himself to the idea of a secret reservoir of implied, extraconstitutional powers vested in the President:

Loose and irresponsible use of adjectives colors all nonlegal and much legal discussion of presidential powers. "Inherent" powers, "implied" powers, "incidental" powers, "plenary" powers, "war" powers and "emergency" powers are used, often interchangeably and without fixed or ascertainable meanings .... The claim of inherent and unrestricted presidential powers has long been a persuasive dialectical weapon

79 Koenig, The Chief Executive 211 (1964).

80 Wilson, Constitutional Government in the United States 77-78 (1908), cited in Levitan, supra note 33 , at 372 n.57. Two other office holders have made their opposing views known. Theodore Roosevelt asserted: "My view was that every executive officer ... was a steward of the people, and not to content himself with the negative merit of keeping his talent undamaged in a napkin. I declined to adopt the view that what was imperatively necessary for the Nation could not be done by the President unless he had some specific authorization to do it. My belief was that it was not only his right but his duty to do anything that the needs of the Nation demanded unless such action was forbidden by the Constitution or the laws." Roosevezt, AN Autoblography 357 (1925).

President Taft, the successor in office, took a contrary approach: "The true view of the Executive functions is, as I conceive it, that the President can exercise no power which cannot be fairly and reasonably traced to some specific grant or justly implied and included within such express grant as proper and necessary to its exercise. Such specific grant must be either in the Federal Constitution or in an act of Congress passed in pursuance thereof. There is no undefined residuum of power which he can exercise because it seems to him to be in the public interest ...." TAFT, Our Chinf Magistrate and His Powers 139-40 (1916) quoted in Roche \& LevY, op. cit. supra note 57, at 23-25.

81 Youngstown Sheet \&: Tube Co. v. Sawyer, 343 U.S. 579 (1952).

$82 I d$. at 641 (Jackson, J., concurring). 
in political controversy. While it is not surprising that counsel should grasp support from such unadjudicated claims of power, a judge cannot accept self-serving press statements of the attorney for one of the interested parties as authority in answering a constitutional question. ... [P]rudence has counseled that actual reliance on such nebulous claims stop short of provoking a judicial test. ${ }^{83}$

A careful reading of the cases yields the conclusion that the courts do not recognize any hidden pockets of undefined executive powers which are not directly traceable to the Constitution. As recently as 1957 in Reid $v$. Covert, ${ }^{84}$ the Court struck down an executive agreement exposing civilians to military trials abroad, declaring:

$[W]$ e reject the idea that when the United States acts against citizens abroad it can do so free of the Bill of Rights. The United States is entirely a creature of the Constitution. Its power and authority have no other source. It can only act in accordance with all the limitations imposed by the Constitution. ${ }^{85}$

Since no sound judicial or historical precedents can be found to support total assumption of the treaty-termination power by the executive, the issue now remains whether the President, to terminate a treaty legally, must act in cooperation with all or part of the legislative branch.

\section{B. Presidential-Senatorial Terminations}

The method of termination which appears to accord with the language of the Constitution most closely would involve "the exercuse of the same kind of power as the making of [a treaty]." ${ }^{86}$ Mr. Justice

$83 \mathrm{Id}$. at 646-47. Mr. Justice Jackson's statement is all the more remarkable in view of the fact that during World War II, as Attorney General for President Franklin D. Roosevelt, Jackson justified the President's seizure of North American Aviation Co. largely on the basis of "inherent" and "aggregate" powers issuing forth from article II grants. 89 Cong. Rec. 3992 (1943); Kurland, Guidelines and the Constitution: Some Random Observations on Presidential Power to Control Prices and Wages, in Guidelines, INFORMaL CoNtrols ANd the Market Place 232 (Shultz \& Aliber eds. 1966).

84354 U.S. I (1957).

85 Id. at 5-6. The court has also impliedly overruled the Curtiss-Wright dicta in Ex parte Quirin, 317 U.S. 1, 25-26 (1942): “Congress and the President, like the courts, possess no power not derived from the Constitution." Thus, it has returned to the position taken by Chief Justice Marshall in MrCulloch v. Maryland, 17 U.S. (4 Wheat.) 316, 405 (1819): "This government is acknowledged by all to be one of enumerated powers .... That principle is now universally admitted." See United States v. Floyd Acceptances, 74 U.S. (7 Wall.) 666, 676-77 (1868). But cf. Kansas v. Colorado 206 U.S. 46, 80-88 (1907).

86 Taft, The Boundaries Between the Executive, the Legislative and the Judicial Branches of the Government, 25 YALE L.J. 599, 610 (1916). 
Story in 1821 determined that: "The obligations of the treaty could not be changed or varied, but by the same formalities with which they were introduced; or, at least, by some act of as high an import, and of as unequivocal an authority." 87 Foreign authorities generally assume that the power to denounce treaties is vested in the same department that concludes them. ${ }^{88}$ James Madison apparently thought that this was the law under the Constitution, ${ }^{89}$ as did Mr. Justice Cardozo when he stated in Techt v. Hughes: "President and Senate may denounce the treaty and thus terminate its life."90

The Senate's role in termination is perhaps best understood by viewing the treaty process as "reverse legislation." It at first appears that the Senate stands in the same position to consent to treaty ratification as the President to approve a bill of Congress. But legislation may become law over the President's "veto" if thereafter passed with a two-thirds vote of both Houses, whereas the President cannot override a Senate "kill" if that body withholds treaty approval. Thus, in theory, treaty law would appear more difficult to enact than legislation. With respect to revocation of statutes or treaties, it has been observed that:

The power to repeal is inherent in the power to legislate, and it would seem that the same formalities would be necessary in both enactment and repeal. Since a treaty cannot become effective either as an international compact or as internal law in the United States until two-thirds of the Senate consent, then can it be terminated internationally or internally without action by the Senate or Congress? ${ }^{91}$

The United States withdrew in 1920 from the International Sanitary Convention of 1903 only after the Senate was consulted by President Wilson and had resolved to "advise and consent to the denunciation of the said Convention." ${ }^{2}$ This action followed a precedent set in 1855

87 The Amiable Isabella, 19 U.S. (6 Wheat.) 1,75 (1821).

88 KUNDERT, VöLKERREGHTLICHER VERTRAG UNd STAATSVERTRAGSTRECHT IM SGHWEIzERISCHEN Rechr 20 (1919), cited in Riesenfeld, The Power of Congress and the President in International Relations: Three Recent Supreme Court Decisions, 25 CALXF. L. REv. 643, 658 n.62 (1937), assumes the identity of treaty-making with the denouncing power as a matter of course.

89 "That the Contracting powers can annul the treaty can not, I presume, be questioned, the same authority, precisely, being exercised in annulling as in making a treaty." I MADIson's WorKs 523-24; cited in 5 MOORE, Digest OF International LAw 321 (1902).

90229 N.Y. 222, 243, 128 N.E. 185, 192 (dictum), cert. denied, 254 U.S. 643 (1920); cited with approval in Clark v. Allen, 331 U.S. 503, 509 (1947).

91 Riggs, Termination of Treaties by the Executive Without Congressional Approval: The Case of the Warsaw Convention, 32 J. ArR L. \& CoM. 526, 531 (1966).

92 MCCluRE, INTERNATIONAL EXECUTIVE AGREEMENTS 21 (1941). 
when the Senate unanimously resolved to authorize President Pierce to give notice pursuant to his request that the 1826 commercial treaty with Denmark be terminated. ${ }^{93}$ Members of the House of Representatives soon protested this procedure on the ground that treaties should be repealed by the full Congress like any other law of the land. This touched off a ringing debate in Congress, during which the newly formed Senate Foreign Relations Committee argued convincingly that the President may rightfully consult the treaty-making department before terminating any treaty which had not required special legislation by Congress to be carried into effect. ${ }^{94}$ It agreed, however, that the President may choose to obtain authority from the whole Congress if "calculated to make the act more impressive upon [the other party to the treaty] than if authorized by the Senate alone . . ."95

\section{Presidential-Congressional Terminations}

Emerging from this nineteenth century controversy is the unmistakable fact that Congress and especially the Senate sedulously guarded the right to terminate treaties as a legislative prerogative, even though conceding that only the President could deliver notice of the final decision to foreign governments. ${ }^{96}$ During the early days of the Constitution, however, many jurists apparently thought that even this function belonged to Congress. The Articles of Conferedation left the entire treaty process to Congress; ${ }^{97}$ and even though the Constitution of 1789 expressly granted this power to the President and Senate, only seven years later $\mathrm{Mr}$. Justice Iredell, discussing the right to give notice of termination, stated:

93 See 1 WilloughBy, op. cit. supra note 48, at 586; Reeves, The Jones Act and the Denunciation of Treaties, 15 AM. J. OF INr'L L. 33, 35 (1921).

94 Foreign Relations Committee Reports, 8th Compilation of Reports of the Committee on Foreign Relations, S. REP. No. 97, 34th Cong., 1st Sess. 107 (1856) [hereinafter cited as S. REP. No. 97]. See MCCluRE, op. cit. supra note 92, at 21; 5 MOORE, op. cit. supra note 89, at 322; Reeves, supra note 93 , at 35 .

85 S. REP. No. 97 11I-12, cited in I WILloughBY, op. cit. supra note 48, at 586-87.

96 The controversy resumed after President Taft had notified Russia in 1911 that the 1832 treaty had to be terminated due to improper treatment of American Jews by that country. Thereafter, he requested approval of that action from the Senate; nevertheless, the full Congress responded with a joint resolution to that same effect. To the contention that the House of Representatives must give its sanction in such cases, Senator Lodge as Chairman of the Senate Foreign Relations Committee replied: "The President has the entire authority to give that notice and to ask for the approval of Congress or the approval of the Senate .... A two-thirds vote would be required in any such case where the President and Senate act alone. This resolution is a joint resolution and requires, of course, only a majority." 5 HACKWORTH, DIGEST OF INTERNATIONAL LAw, 320-22 (1943), citing 48 CONG. REC. 455-79 (1912).

97 articles of Confederation art. VI, $\mathbb{\text { If }}$ 2. See, e.g., The Constitution of the United States of America: ANALYsis and Interpretation 465 (Corwin ed. 1964). 
If congress, therefore, (who, I conceive, alone shall have such authority under our government), shall make such a declaration, in any case like the present, I shall deem it my duty to regard the treaty as void ....

[O]ur judgment must be grounded on the solemn declaration of congress alone (to whom, I conceive, the authority is entrusted), given for the very purpose of vacating the treaty, on the principles I have stated.98

Two years later, Congress bluntly exercised this authority by passing a joint resolution pronouncing the United States "freed and exonerated from the stipulations of the treaties" of 1778 with France.99 Judge Sewall, then a representative from Massachusetts, remarked upon the passage of the bill: "In most countries it is in the power of the Chief Magistrate to suspend a treaty whenever he thinks proper; here Congress only has that power."100

As late as 1871, a circuit court held that Congress had the right to give notice of denunciation to other countries; ${ }^{101}$ but this has since been restricted to declarations pursuant to war. ${ }^{102}$ Nevertheless, Congress has undisputed authority to suspend or abrogate the internal

98 Ware v. Hylton, 3 U.S. (3 Dall.) 199, 260-61 (1796) (emphasis added).

991 Stat. 578 (1798). But this abrogation was later treated by the Senate in S. REP. No. 97, 34th Cong., 1st Sess. 4 (1856), and by the Supreme Court in Bas v. Tingy, 4 U.S. (4 Dall.) $37(1800)$, as a partial declaration of war. Whether the act of Congress was formally brought to the attention of the French Government does not appear. CorwrN, op. cit. supra note 57, at $435 \mathrm{n.75}$; Riesenfeld, supra note 88 , at 659 n.67. But the Court of Claims in The Ship James \& William v. United States, 37 Ct. Cl. 303, 306 (1902), said: "In, July 1798, the United States abrogated the treaty in toto, and thereby relieved France from all obliga. tions made under it." (Emphasis added.) And in Hooper v. United States, $22 \mathrm{Ct} . \mathrm{Cl} .408$, 425 (1887): "We are of the opinion that the circumstances justified the United States in annulling the treaties of 1778; that the act was a valid one, not only as a municipal statute but as between the nations; and that thereafter the compacts were ended." See Crandall, Treaties: Their Making and Enforcement 463 n.138 (2d ed. 1916); Sinha, Unilateral Denunciation of Treaty Because of Prior Violations of Obligations by Other Party 44-45 (1966).

1002 Annais of Conc. 2120; see Reeves, supra note 93, at 36.

101 In Ropes v. Clinch, 20 Fed. Cas. 1171 (No. 12041) (G.C.S.D.N.Y. 1871), the federal court described three modes "in which Congress may practically yet efficiently annul or destroy the operative effect of any treaty with a foreign country." One of these was "by giving the notice which the treaty contemplates shall be given before it shall be abrogated, in cases in which, like the present, such a notice was provided for . . ." Ibid. See generally Riesenfeld, supra note 88, at 659; cf. Taylor v. Morton, 23 Fed. Cas. 784 (No. 13799) (C.C.D. Mass. 1855); Riggs, supra note 91, at 531 .

102 Clark v. Allen, 331 U.S. 503 (1947); The Chinese Exclusion Case, 130 U.S. 581, 600-02 (1889); The Head Money Cases, 112 U.S. 580, 597-99 (1884); Argento v. Horn, 241 F.2d 258 (6th Cir. 1957). 
operation of a treaty by subsequent, inconsistent legislation. ${ }^{103}$ In such event, the President would seem bound to terminate the international portion of the treaty, not only because he must "take Care that the Laws be faithfully executed," 104 but also to avoid international delinquency. However, where the treaty contains no provision for termination by notice, Congress may not obligate the President to breach the compact. Thus, President Wilson refused to enforce Section 34 of the Jones Merchant Marine Act, which required termination of over thirty commercial treaties containing no provision for termination by notice. ${ }^{105}$

Further strengthening Congress' claim to the authority to terminate are numerous instances in which the President has requested permission and authority from Congress to terminate; ${ }^{106}$ in still other cases, Congress has ordered the President to give notice "at his discretion"107 and as "charged and directed." 108 In summary, notice of treaty termination has usually been given under the authority of a joint resolution of

103 "It is established doctrine that when a treaty and statute conflict, the maxim 'leges posteriores priores contrarias abrogant' applies in the same manner that it would in the case of conflict between two treaties or two Acts of Congress." Corwin, The President: OFfice AND Powers 424 (4th ed. 1957). See Rainey v. United States, 232 U.S. 310,316 (1914); La Abra Silver Mining Co. v. United States, 175 U.S. 423, 460 (1899); Boliller v. Dominguez, 130 U.S. 238, 247 (1889); Whitney v. Robertson, 124 U.S. 190, 194 (1888); The Head Money Cases, 112 U.S. 580, 599 (1884) (a treaty is "subject to such acts as Congress may pass for its enforcement, modification or repeal'); The Cherokee Tobacco, 78 U.S. (11 Wall.) 616, 621 (1870).

104 U.S. CoNsT. art. II, \& 3.

105 Justifying the President's refusal to terminate as contemplated by Congress, Secretary of State Hughes said: "Action by Congress, in disregard of a treaty, may be justified by the principles governing the operation of contracts in case the action is (I) in accordance with the terms of the treaty; or (2) in accordance with a condition fairly implied in the treaty; or (3) based on the breach of the treaty by the other party. Otherwise, action by the Congress, taken without the consent of the other party to a treaty and inconsistent with its provisions, is merely a violation of the treaty and a breach of faith. . . . Congress has the power to violate treaties, but if they are violated the Nation will be none the less exposed to all the international consequences . . . Memorandum for President Harding, Oct. 8, 1925, Ms. Dep't of State, file 195/389, reprinted in 5 HACKWortF, op. cit. supra note 96 , at 325 .

106 The Constitution of the United States of America: ANalysis and Interpretation 474 n.72 (Corwin ed. 1964).

107 Numerous instances of "discretionary" authorization are cited in MCCLURE, INTERNATIONAI Executive Agreements 22 (1941).

108 For example, the Joint Resolution of Congress of January 18, 1865, declared that the Canadian Reciprocity Treaty should be terminated and that "the President of the United States is hereby charged with the communication of such notice." 13 Stat. 566 (1865). Of the same tenor was the Joint Resolution of March 3, 1883, relative to the Treaty of Washington of 1871 with Great Britain. 22 Stat. 641 (1883). See MCCLURE, op. cit. supra note 107, at 22. 
Congress, ${ }^{109}$ though it is evident that the President is bound to consult only with the Senate.

As a final argument for unilateral executive power, it has been asserted that, whatever de jure authority to denounce treaties the President may or may not enjoy, nevertheless, by virtue of his superior position when dealing with foreign affairs, he may release the nation from its treaty obligations with a foreign party which is "entitled to rely upon such [presidential] notice without inquiring into the constitutional authority of the President to speak for the nation in such matters." 110 The issue has never been litigated. But if it were, some maintain that it is not at all certain that the courts would not uphold the treaty as binding internal law even though the President acting alone had terminated the treaty as an international contract. ${ }^{111}$ In any event, whereas the argument in favor of independent executive authority to terminate falls short of constitutional correctness, the argument for a presidential fait accompli without regard for congressional approval proves too much, since there is no international agency established to force any country to honor its commitments or to disregard a party's extra-constitutional actions. ${ }^{112}$ Furthermore, while it

109 The Constitution of the United States of America: Analysis and Interpretation 474, 476 (Corwin ed. 1964); 2 Haynes, The Senate of the United States 670 (1938); 5 Moore, International Law Digest 322 (1906); Norton, Constitution of the United STATES: SOURGES AND APPLICATION 115 (1943).

110 Memorandum of the Legal Advisor of the Dept. of State, Jan. 27, 1936, reprinted in 5 HAckworth, op. cit. supra note 96, at 328. Professor Wright notes that the President's international actions "have definite effects as far as the obligation of the other state is concerned under international law, and that no amount of Congressional or Senatorial closing of the barn door can bring back the departed horse." WriGHT, Constitutional Power to Revise Debt Setrlements 3 (1932), cited in Levitan, Executive Agreements: A Study of the Executive in the Control of the Foreign Relations of the United States, 35 Ixx. L. Rxv. 365, 385 (1940). Consider the further observation by Bishop: "[T]here seems to be no legal method of constraint upon the freedom of executive discretion in matters of foreign affairs-save in so far as the possibility of impeachment may lie in the background." Bishop, The Structure of Federal Power Over Foreign Affairs, 36 Mins. L. Rev. 299, 301 (1952).

111 Riggs, supra note 91, at 528, 533-34; cf. Crandall, op. cit. supra note 99, at 460, 465.

112 From a strictly legal standpoint, the preponderance of authority agrees that an agent's competence to bind a state internationally is determined by national law, and that foreign states are held to a knowledge of the more obvious constitutional provisions. Foster, Practice of Diplomacy 276 (1929); 1 Willoughby, The Constitutronal law of the United States 527-29 (1929); Wright, Control of Foreign Relations 44 (1922); Fairman, Competence to Bind the State, 30 AM. J. INT. L. 441, 445, 452-54 (1936); Levitan, supra note 110, at 372-73. Contra, 5 HACKwORTH, op. cit. supra note 96, at 393; Bishop, Unconstitutional Treaties, 42 MiNN. L. REv. 773, 793 n.51, 799, 801 (1959). Thus, for example, even though the President has signed a treaty, it would not become law until the Senate concurred by constitutional mandate. It is probably true that the more "notorious" and clearcut the constitutional provision may be, the quicker its violation should be recognized as a nullity. Bishop, supra at 801 . But even though the Constitution is verbally silent regard- 
is evident that the President occupies a position of great power and trust when acting in the sphere of foreign relations, he is nonetheless required by the electorate and the oath of office to execute this position in good faith. Thus, although it is unlikely that the President would consciously violate his obligations, even if in the position to do so, the final impediment to precipitous executive actions may be of a political nature, ${ }^{113}$ depending upon an aroused Congress or public.

\section{The Power To Modify Treaties}

Related to the termination of treaties is their revision or amendment, since any major change in treaty provisions is considered a rescission of the old treaty and replacement with a new one. ${ }^{114}$ Supporting the legal treatment of proposed modifications to an existing treaty as terms for a new treaty, requiring Senate approval to complete, is the near-uniform practice of the executive branch itself. Desired changes in treaties governing such diverse factors as extraterritorial rights and boundaries, tariff rates, transfer of duties, effective date of the treaty, diversion of boundary waters, and tenure of officials have all been deferred by the Department of State until the Senate had voiced its consent, on the ground that any change in the terms of a treaty "would be a partial abrogation of that treaty, which would require the concurrence of the legislative branch of the Government."115 This fundamental requirement would appear all the more

ing the explicit manner of terminating treaties, its entire language more closely supports legislative participation, and a case could be made for a treaty's continuing validity absent that cooperation, which the foreign party may observe or disregard. But the confusion regarding the properly designated agency to terminate treaties, when coupled with the rapid abdication of that authority by Congress, renders unconvincing any prospect that a foreign party would be found guilty of breach by accepting presidential termination as final.

113 "Of course no President or Secretary of State will in practice disregard the views of Congress or of its more influential members, any more than they will disregard public opinion." Bishop, supra note 110 , at 301 .

114 Lord McNair has stated some prerequisites for treaty modification: "As a question of law, there is not much to be said upon the revision of treaties. It frequently happens that a change in circumstances may induce a Government on political grounds to accede to the request of another Government for the termination of a treaty and for its revision in the light of new circumstances. But, as a matter of principle, no State has a legal right to demand the revision of a treaty in the absence of some provision to that effect contained in that treaty ... [A] revised treaty is a new treaty, and, subject to the same limitation, no State is legally obligated to conclude a treaty." MCNAIR, The LAW of Treaties 534 (1961).

1155 HAckworth, op. cit. supra note 96, at 333; see generally id. at 333-37. As to whether Congress may authorize modification of treaties, President Hayes in his March 1, 1879, message to the House of Representatives, said: "As the power of modifying an existing treaty, whether by adding or striking out provisions, is a part of the treaty-making power under the Constitution, its exercise is not competent for Congress ...." 9 Richardson, 
necessary when the subject matter of a treaty, like the Warsaw Convention, relates to commerce, with which the courts have held that the President has no power to deal unless expressly authorized by Congress. ${ }^{118}$

The general rules for treaty modification, however, are marked with frequent exceptions. By mere exchange of diplomatic notes, the President has interpreted the meaning of treaties, ${ }^{117}$ temporarily suspended the operation of a treaty or extended its duration, ${ }^{118}$ agreed to minor administrative changes, ${ }^{119}$ and even tacitly acquiesced in some actions by foreign parties which had the effect of revision. ${ }^{120}$

Messages and Papers of the Presidents 4466 (1899), cited in Crandale, op. cit. supra note 99, at 460 n.130; see The Constitution of the UNited States of AmeriaA: ANalysis and INTERPRETATION $475 \mathrm{n} .72$ (Corwin ed. 1964). The Solicitor for the Department of State emphasized in 1920: "Congress may pass an act violative of a treaty. It may express its sense that a treaty should be terminated. But it cannot in effect undertake legally to modify a treaty no matter what methods it may employ. In doing that it, in effect, attempts to conduct diplomatic negotiations and to encroach on the Treaty-making power composed of the President and the Senate." N.Y. Times, Sept. 25, 1920, p. 1, col. 1, reprinted in 5 HAckWORTK, op. cit. supra note 96, at 324. But see Whitney v. Robertson, 124 U.S. 190, 194 (1887); The Head Money Cases, 112 U.S. 580, 597-99 (1884).

116 In United States v. Guy W. Capps, Inc., 204 F.2d 655 (4th Cir. 1953), the Fourth Circuit invalidated a presidential agreement regulating the importation of Canadian potatoes on the grounds that (1) it contravened a prior act of Congress, and (2) Congress had not authorized the President to make such an agreement. In broad terms, the court declared: "The power to regulate foreign commerce is vested in Congress, not in the Executive or the courts; and the Executive may not exercise the power by entering into executive agreements ....'Id. at 658. This expressly contradicted the district court's statement that "the President through his Secretary of State or other representative may, without the authorization or approval of the Congress, enter into commercial compacts." $100 \mathrm{~F}$. Supp. 30, 32 (E.D. Va. 1951). Even though the Supreme Court affirmed on other grounds, 348 U.S. 296 (1955), the proposition that foreign commerce is exclusively within Congress' control was reaffirmed in Best Foods v. United States, 158 F. Supp. 583 (Customs 1957). In at least one other recent case, a court has declared part of an executive commercial proclamation ultra vires and void "for the reason that . . . the President exceeded the powers conferred upon him by the Trade Agreements Extension Act of 1945." American Bitumuls \& Asphalt Co. v. United States, 146 F. Supp. 703, 710 (1956).

117 MCCluRE, op. cit. supra note 107, at 37; Borchard, Treaties and Executive Agreements-A Reply, 54 Yale L.J. 616, 652 n.143 (1945). Contra, 1 Willoughby, Principles of Constitutional Law of the UNited States 232 (2d ed. 1938).

118 See 5 HACKWORTH, op. cit. supra note 96, at 324-26.

119 On one notable occasion, the President through the Secretary of State agreed to extend the six-month time limit provided by the "Bryan peace treaties" for the organization of commissions following the ratifications of the respective treaties, when it turned out that the agreed limit was too restrictive. 5 HAckwORTR, op. cit. supra note 96, at 337; MCClURE, op. cit. supra note 107, at 27 . That these minor and temporary changes were not regarded as having any practical or long-range effect on the operation of the treaties themselves is evidenced by the fact that, when requested by Italy to modify those same treaties so that the commissioners would serve indefinite terms rather than the five-year period established by the treaty, the Department of State forthwith refused to do so by mere exchange of notes, but instead requested a new treaty for that purpose. HACkWORTH, supra at 335 .

120 The Department of State Counselor has explained: "The President is, of course, 
As with the authority to terminate treaties, it is apparent that the power to change or substitute major treaty provisions is shifting from the legislative branch to the President. In the case of the Warsaw Convention, the Department of State did not "tacitly acquiesce" in the carrier modification, but actively set forth the terms of the agreement. Moreover, carrier liability limitations are not mere administrative details; ${ }^{121}$ as major terms, any revision thereof represents a substantially new treaty which should be approved by the Senate. Inasmuch as a treaty is a contract between nations, the analogy to the contractual doctrine of "substantial performance" is presented. Any alteration of terms which materially defeats the original purpose of the contracting parties would prevent the agreement from being "substantially performed," and would result in a breach unless a new contract is made. ${ }^{122}$ Thus, when the President agreed at The Hague to raise limits on carrier liability, this modification of the Warsaw Convention did not become immediately effective in the United States, but was contingent upon Senate consent. Accordingly, had the President agreed with treaty members in Montreal during February 1966 to further amend the Warsaw limits, this modification would also have required a Senate vote.

Although the modifying Montreal Agreement was technically among private carriers and not Warsaw signatories, the practical effect is the same as if the treaty had been formally amended. The carriers are the "true parties in interest" and beneficiaries of the treaty, being primarily affected by any change in its provisions. This is even more significant in view of the fact that most foreign airlines are nationally owned and merely expressed their government's desires by signing the new agreement. Furthermore, the revising terms when filed with the Civil Aeronautics Bureau bind the carriers with all the force of an

without authority except by and with the advice and consent of the Senate, to modify a treaty provision. There are, however, instances in which he, acting through the Secretary of State, has tacitly acquiesced in action by foreign governments which had the effect of modifying stipulations in our treaties." Ms. Dept. of State, file 893.512/31, May 4, 1914, reprinted in 5 HACKWORTH, op. cit. supra note 96 , at 340 . In the case in point, a sequence of changes effected between China and other nations regarding customs tariffs within its borders was accepted by the Executive as binding even though most of the revisions were not approved by the Senate until much later.

121 The Warsaw Convention was primarily framed for the purpose of "fixing the liability of air carriers and limiting that liability in the matter of air transport." Minutes of the French Delegation, 2d International Conference on Private Air Law in Warsaw, 1 Oct. 4-12, 1929, p. 155, cited in Karlin, Warsaw, Hague, the 88th Congress and Limited Damages in International Air Crashes, 12 DE PAUL L. Rev. 59, 61 n.4 (1963).

122 Sinha seems to suggest a test of substantial breach: whether a party could justifiably relinquish its treaty obligations upon actions by the other party which materially deviate from the original intent and purpose of the treaty. See SiNHA, op. cit. supra note 99, at 84-88. 
international treaty unless the Board allows them to withdraw, pending approval by the President himself. ${ }^{123}$

The State Department contends that, by persuading the carriers privately to alter the terms of the Warsaw Convention, the Government actually complied with the treaty's own provisions for modification. ${ }^{124}$ In this respect, the Convention specifies only two procedures: (1) Any contracting party may call an international assembly to discuss possible improvement;"125 or (2) "by special contract, the carrier and the passenger may agree to a higher limit of liability."126 The first provision does not fit the facts of the Montreal carrier agreement, and the second requires the passenger to be a party to the agreement. Moreover, the language of Article 22 bespeaks a special contract and does not persuasively support authorization for a broad agreement among many or all carriers to agree in futuro to a higher limit of liability as to all passengers, particularly if arranged by one of the contracting parties' as a means of avoiding the method provided for general revision by formal amendment at an international conference. It is true that some countries have raised the limitations on their own national airlines, presumably under authority of the "special contract" clause of Article 22; but no country has attempted to fix higher limitations on other carriers. ${ }^{127}$ Even as applied domestically, the British have interpreted that clause to allow only for voluntary agreements between carrier and passenger unless "British carriers were persuaded to do so by the Minister with the authority of Parliament ....".128

Consultation with Congress or the Senate before imposing new "interim" conditions upon the carriers has been explained as "clearly impractical"129 due to the impending deadline for complete termina-

123 Section 403 of the Federal Aviation Act of 1958 requires that all carriers file changes in tariffs, rates, etc., with the $\mathrm{CAB}$, which by the terms of section 412 must then approve or reject them according to federal policies. The President by $\S 801$ has the privilege of ratifying all carrier rates, certificates, changes, etc. Section 1102, however, specifically requires that no policy or rate be established which is inconsistent with international treaties and conventions. Givil Aeronautics Act, 49 U.S.C. $\S \S 483,492,601,672$ (1958).

124 Dep't of State Document, May 5, 1966, reprinted in 32 J. Arr L. \& CoM. 243-44 (1966). 125 Warsaw Convention art. 41.

126 Warsaw Convention art. 22(1).

127 Sand, Air Carrier's Limitation of Liability and Air Passengers' Accident Compensation Under the Warsaw Convention, 28 J. AIR L. \& CoM. 260, 275 n.146 (1962).

Apart from the matter of higher liability, there is no implication to be drawn from any corner of the treaty that imposition of strict liability by gxoup waiver of defenses reserved to the carriers by article 20(1) can be achieved in any way but by international conference.

128 Caplan, British Business Law, 1961 J. Bus. L. 282 (emphasis added); Sand, supra note 127, at $266 \mathrm{n} .65$.

129 Lowenfeld \& Mendelsohn, The United States and the Warsaw Convention, 80 Harv. L. REv. 497, 594 (1967). 
tion of United States membership in the treaty. However, the Executive should be estopped from using this excuse, since it was that branch of government which knowingly created the cause of that "impracticality" by denouncing the treaty. Lowenfeld and Mendelsohn foresaw the advisability of legislative consent and the possible impact of its omission:

Consultations under these circumstances seemed essential, since the arrangement, though characterized as "interim," would have no terminal date and might well continue until a new treaty was negotiated and brought into effect. Thus, not only could it be argued that a treaty would in effect be amended without the advice and consent of the Senate, but a new standard of tort liability would be imposed with respect to international air transportation-a standard that would certainly be controversial and could fairly be termed a major departure from the common law principle of liability only for fault. ${ }^{130}$

\section{Executive Latitude in Practice and Theory}

Separate from the legal significance of the actions of the executive branch with respect to the Warsaw Convention is the need to examine whether in some cases the President might be best situated to decide on treaty amendment or termination. Of primary concern is the extent to which the original conceptions of the executive office and its relationship to the legislative branch in such matters remain viable today.

With memories of the tyrannies produced by a unified executive and legislative power, the Framers of the Constitution applied to both foreign and domestic affairs the principle of checks and balances. ${ }^{131}$ Even as vigorous an exponent of executive powers as Hamilton vividly

130 Id. at 588. The Administration did convene a briefing session with the Senate Committee on Foreign Relations to explain the interim plan, but it was afterwards reported that: "Underlying the discussion was the uneasy feeling that, right or wrong, the Administration could be accused of doing something by executive act that properly fell within the prerogative of Congress." Id. at 595.

131 Corwin, The President: Office and Powers 1787-1957, 416 n.I (4th ed. 1957), claims that: "At no point did the Framers depart more conspicuously from their materials than in dispersing among the President, Congress, and the Senate the powers most immediately touching the conduct of foreign relations . . . B Blackstone, Locke, and Montesquieu were all in agreement in treating the direction of foreign affairs as a branch of 'executive,' or royal, power." But the Framers appeared convinced that they were following the teachings of those minds consistently throughout. Said Madison in THE FEDERALIST No. 47, at 302-03 (Rossiter ed. 1961): "On the slightest view of the British Constitution, we must perceive that the legislative, executive, and judiciary departments are by no means totally separate and distinct from each other. The executive magistrate forms an integral part of 
explained why the President was not given complete power to make treaties with foreign nations:

The history of human conduct does not warrant that exalted opinion of human virtue which would make it wise in a nation to commit interests of so delicate and momentous a kind, as those which concern its intercourse with the rest of the world, to the sole disposal of a magistrate created and circumstanced as would be a President of the United States. ${ }^{132}$

The Framers intended that the Senate, as the President's partner in treaty-making, become, rather than a subservient collaborator in executive policy making, primarily a critic of proposals. ${ }^{133}$ Its real power in treaty making is not merely a mechanical one; it is the Senate's ability to provide a "ventilating chamber" for public discussion of issues, to awaken doubts, and to secure popular support for courses other than those proposed by the President.

When presented to the Senate Foreign Relations Committee, the Administration's proposed reforms of the Warsaw Convention immediately provoked both public and legislative controversy. Although all witnesses agreed that the Warsaw limitation was inadequate, all non-governmental witnesses opposed the prospect of absolute carrier

the legislative authority. He alone has the prerogative of making treaties . . . . From these facts, by which Montesquieu was guided, it may clearly be inferred that in saying 'There can be no liberty where the legislative and executive powers are united in the same person, or body of magistrates ... ' (h)is meaning ... can amount to no more than this, that where the whole power of one department is exercised by the same hands which possess the whole power of another department, the fundamental principles of a free constitution are subverted."

Mr. Justice Frankfurter emphasized the current necessity for this doctrine in Youngstown Sheet \& Tube Co. v. Sawyer, 343 U.S. 579, 593-94 (1952): "For [the Founders of this Nation] the doctrine of separation of powers was not mere theory; it was a felt necessity. Not so long ago it was fashionable to find our system of checks and balances obstructive to effective government. It was easy to ridicule that system as outmoded-too easy. The experience through which the world has passed in our own day has made vivid the realization that the Framers of our Constitution were not inexperienced doctrinaires. These long-headed statesmen had no illusion that our people enjoyed biological or psychological or sociological immunities from the hazards of concentrated power. It is absurd to see a dictator in a representative product of the sturdy democratic traditions of the Mississippi Valley. The accretion of dangerous power does not come in a day. It does come, however slowly, from the generative force of unchecked disregard of the restrictions that fence in even the most disinterested assertion of authority."

132 The Federalist No. 75, at 451 (Rossiter ed. 1961) (Hamilton).

133 The Constitution of the United States of America: ANalysis and Interpretation 462 (Corwin ed. 1964); Byrd, Treaties and Executive Agreements in the United States 34-35 (1960). Patrick Henry was particularly dubious of the Senate's integrity and felt that for the right price it would, with the President, "combine and be as one." 3 Errrotr, DEbates ON THE FEDERAL Constitution 353 (2d ed. 1863). 
liability, ${ }^{134}$ which would prevent the airlines from disclaiming liability for disasters caused by such unavoidable phenomena as lightning, flying geese, and sabotage. ${ }^{135}$ The twin goals expressed by the Department of State in defense of strict liability-lessening litigation and "guaranteeing the broadest possible protection for the . . . traveling public"136 -are open to serious doubt. The passenger must still litigate the amount of his damages unless the carrier makes voluntary settlement. Also, the additional cost of accident insurance by the carriers may ultimately be borne by the passengers themselves in the form of increased fares. ${ }^{137}$ Finally, rather than protecting passengers, strict liability may unduly jeopardize them by inviting sabotage, since a key clue to the detection of saboteurs-high insurance purchases-is eliminated.138 Whether wise or not, conditions even more stringent than those controverted and disapproved by Congress were imposed upon private parties only months thereafter by independent presidential pressures, ${ }^{139}$ without recourse to salutary public debate.

It is, of course, clear that in many situations, particularly in times of crisis and emergency, the executive office is better suited for independent action than the Congress. Drawing on the sources of an informed international diplomatic network, the President is in a position to reach immediate decisions as world conditions abruptly change. Unlike Congress, the President is always "in session." Speed and permanency, when coupled with the secrecy inherent in the executive branch, enable the President to involve the nation in many arrangements vital to its security. Rapid and necessarily secret troop mobilizations, for example, must frequently be accomplished for the common defense. In order to expedite the treaty process, the Founders are said to have favored the Senate rather than the full Congress as treaty concomitant to the President, in part, at least, because its size aided speed and secrecy. ${ }^{140}$ Nevertheless, military necessities have required

134 Lowenfeld \& Mendelsohn, supra note 129, at 545-46; Kreindler, The Denunciation of the Warsaw Convention, 31 J. Air L. \& Com. 291, 297 (1965).

135 At the same time the Administration was proposing strict liability, domestic policies were moving away from such doctrines with regard to air carriers. See Wood v. United Air Lines, Inc., 223 N.Y.S.2d 692 (1961).

136 Dep't of State Letter, supra note 124, at 246.

1371965 Senate Hearings 115-16.

138 See Lowenfeld \& Mendelsohn, supra note 129, at 538-39, 592-93.

139 In addition to the threat of treaty denunciation, other possible pressures available for use by the President against private carriers could include curtailment of postal franchises, termination of subsidy funds, and withholding of favored domestic and foreign air routes.

140 See, e.g., United States v. Curtiss-Wright Exp. Corp., 299 U.S. 304, 320-21 (1936); The Federalust No. 64 (Jay); 1 Richardson, Messages and Papers of the Presments 194-95 (1900), BYRD, op. cit. supra note 133, at 25-28; McLaughlin, The Scope of the Treaty 
that several thousand private executive agreements be reached under NATO alone without public disclosure or Senate confirmation.141

Certainly Congress or even the Senate would soon lose any semblance of efficiency if required to act as a clearing house for the plethora of daily details and minor changes related to the administration of every existing treaty. This burden is usually obviated by revision clauses within the treaty itself which, when approved by the Senate, allow the President considerable latitude. ${ }^{142}$ Even if the treaty does not expressly provide for revision, the President should perhaps be able to implement minor changes as new conditions demand. But independent executive action in treaty arrangements should be strictly confined to situations where speed is necessary or where the routine nature of the changes make consultation inappropriate.

Regardless of the advantages inherent in the executive branch, the image of an omniscient President faithfully executing the laws and personally attending to executive duties with discipline, foreknowledge, and expertise is generally a myth. In reality, the President does little by himself. $\mathrm{He}$ is surrounded by non-elected staff members, agencies, bureaus, advisors, and councils numbering over 1500 persons. ${ }^{143}$ As a result, it is argued that decision-making in the executive branch closely parallels crowd behavior ${ }^{144}$ and often involves more individuals than when similar issues are resolved by Congress. It is possible that more persons occupy themselves with executive than with legislative policy and for longer periods of time. For example, proposed Warsaw Convention improvements were before committees in Congress for less than three years whereas they were entrusted with various executive agencies for more than twice that period, eventually emerging under the guise of studied proposals which were, at least in part, admittedly arbitrary. ${ }^{145}$ Despite presidential permanency, so

Power in the United States, 42 MiNN. L. REv. 709, 738-39 (1958). Even though Senate membership has measurably increased since 1789, still it is far easier for 100 Senators to hold a closed session than it is for 435 Representatives.

141 Colloquy between Secretary of State Dulles and Senator Watkins in Hearings on S.J. Res. I and S.J. Res. 43 Before a Subcommittee of the Senate Committee on the Judiciary, 83d Cong., 1st Sess., 881, 887 (1953); BYRD, op. cit. supra note 133, at 132 n.23.

142 For types of revision clauses commonly inserted to update treaties, see WiLlovgriby, op. cit. supra note 112, at 543; McLaughlin, supra note 140, at 767; Wilson, supra note 120, at 901-09.

143 de Grazia, Republic IN Crusrs 70 (1965); Somers, The President as Administrator, in The President: Roles and Powers 160, 166 (Haight \& Johnson eds. 1965).

144 DE GRAZXA, op. cit. supra note 143, at 71; Somers, supra note 143, at 161-62.

145 In addition to the unresolved issue of absolute liability imposed upon carriers, the liability limitation was changed three times within a matter of weeks by the Administration. Before Congress, State Department witnesses first proposed insurance of $\$ 50,000$, admitting that this amount was "arbitrary, of course-as any such figure must be." 1965 Senate Hearings 5. To justify the next figure of $\$ 100,000$ proposed to the carriers and at 
much of the Chief Executive's time is occupied by the many menial tasks of office--such as naming ships, greeting foreign potentates, signing letters and documents, and appointing minor officials-that his opportunity closely to supervise the countless activities of his appointed subordinates is manifestly impossible. Thus, headlined "executive programs" affecting broad segments of society may be bureau-born and executed without more than bare and superficial knowledge of the President. ${ }^{146}$

Congress is the constitutionally designated body to restrain or redirect executive action. From this role emerges the popular image of that body as recalcitrant, obstructive, and reactionary. By exposing its complicated and often irrational operations to public scrutiny, Congress incurs a reputation as a cumbersome, time-consuming, and inefficient body. ${ }^{147}$ The President, on the other hand, usually enjoys the image of action, speed, and dispatch: "the power to get things done."148 But even the presidential office, though it has frequently been occupied by skillful practitioners, cannot be declared categorically one of inherent expertise ${ }^{149}$ or even ordinary efficiency in its daily operations. Nevertheless, this government has been structured so that the actions

Montreal, the Administration reasoned that the claimant must "gross" that amount in order to "net" $\$ 66,600$ after attorney's fees were deducted. Kreindler, supra note 134, at 301. There was similar lack of supporting evidence for the eventual $\$ 75,000$ imposed by carrier accession. As a matter of fact, $\mathrm{CAB}$ studies on file indicate that the average nonWarsaw death award is considerably below the Government's predictions. 1965 Senate Hearings 29-38.

146 Cf. DE GRAZIA, op. cit. supra note 143, at 75.

147 See Youngstown Sheet \& Tube Co. v. Sawyer, 343 U.S. 579, 629 (1952) (Douglas, J., concurring).

148 DE GRAZIA, op. cit. supra note 143, at 72. The President, with a multitude of "emergency," "crash," and "crisis" programs with high-flown slogans formed to meet foreign aggression or domestic crises, conveys the impression of creativity, energy, and progress. But with regard to the innovation and implementation of measures "in the public interest," the survey in Chamberlain, The President, Congress and Legislation, 61 Pol. Sci. Q. $42-60$ (1946), reprinted in THE President: Roles and Powers, at 297-310 (Haight \& Johnson eds. 1965), shows that the Congress over a period of half a century was the source of many more important laws than was the Presidency. Furthermore, many executive ideas such as the Peace Corps originate or are developed by congressmen. See $\mathrm{DE}$ GrazIs, op. cit. supra note 143, at 92. Thus, it is clear that Congress' role is not only to block or approve executive proposals, but also to evolve measures of reform, meet emergencies and oversee social well-being.

149 Comparing the occupants of both the legislative and executive branches so far as knowledge and expertise is concerned, the Second Hoover Commission reported: "Much of the activity of government noncareer executives involves the Congress, and in these relationships the Congressmen easily outweigh the government executives in federal political experience. ... The vast task of taking command of departments and agencies, developing policies and programs and defending these before the Congress and public as well as before presidential staff arms . . overwhelms the noncareer executives." Commission on Organization of the Executive Branch of the GovernMent, Personnel and CrvIL SERVICE, REPORT 26-27 (1955). See also de GrazIA, op. cit. supra note 143, at 89. 
of one fallible branch may be reviewed in public by another. ${ }^{150}$ If efficiency is judged in terms of longevity, stability, and flexibility of institutions in promoting progress through preservation of individual liberties, history should vindicate this constitutional structure as one of true long-range efficiency. ${ }^{151}$ Its degeneration will come only, as Mr. Justice Frankfurter stressed, from "unchecked disregard of the restrictions that fence in even the most disinterested assertion of authority." 162

Of particular concern in view of the increasing interdependence between foreign and domestic affairs is the President's expanding control over commercial treaties. During the constitutional debates, delegates noted that the treaty process could easily determine the extent of domestic as well as foreign policies. John Rutledge, for example, spoke of "an obvious difference between treaties of peace and those of commerce." 153 To prevent interference in local matters, some delegates proposed more stringent limitations on federal power than a two-thirds majority of those Senators present to enact treaties regulating commerce. Some preferred a two-thirds vote of all Senators, and others a vote by that margin in both Houses of Congress as a means of procuring greater public discussion where private interests are involved. ${ }^{154}$

It has been suggested that restraints upon the President's power to terminate or modify treaties may hamper national bargaining power at the conference table. ${ }^{155}$ But consider the position of Dean Roscoe Pound:

150 Myers v. United States, 272 U.S. 52, 293 (1926) (Brandeis, J., dissenting): "The doctrine of the separation of powers was adopted by the Convention of 1787, not to promote efficiency but to preclude the exercise of arbitrary power. The purpose was, not to avoid friction, but, by means of the inevitable friction incident to the distribution of the governmental powers among three departments, to save the people from autocracy."

151 See BYRD, op. cit. supra note 133, at 193: "A political theorist who equates good government with efficient government and efficient government with simplicity would condemn this system as outrageously complex. But efficient government must be judged in terms of the time element. A government may be highly inefficient over a shortterm interval, yet highly efficient over a longterm interval. If stability combined with orderly change is deemed to be the criteria of efficiency, then the United States Government is very generally considered to be the most efficient on earth."

152 Youngstown Sheet \& Tube Co. v. Sawyer, 343 U.S. 579, 594 (1952) (Frankfurter, J., concurring).

153 BYRD, op. cit. supra note 133, at 32. Fearful that Senate consideration of treaty proposals would not afford sufficient public discussion, both Madison and Jefferson purportedly took the position during the mid-1790's that commercial arrangements with other nations should be made only by majority vote of both Houses of Congress. McDougal \& Lans, Treaties and Congressional-Executive or Presidential Agreements: Interchangeable Instruments of National Policy, 54 YALE L.J. 534, 542 (1945).

154 See BYRD, op. cit. supra note 133, at 31-33.

155 See, e.g., Nelson, The Termination of Treaties and Executive Agreements by the United States: Theory and Practice, 42 MiN. L. REv. 879, 887 (1958). 
I have no patience with the argument so often made that the exigencies of international relations in the unifying world of today require that the national executive be free from constitutional restraints in bargaining with foreign nations. I agree that the executive ought not to be subjected to too much participation by legislative bodies. But all the powers of government in our polity must be exercised within the limits of the Constitution, and the increased importance of international relations in the world of the time only calls for the more insistence upon keeping the national executive within those limits in this domain also. ${ }^{156}$

Certainly, a requirement that all threats, tactics, or propositions advanced during treaty negotiations must be approved by the legislature would so fetter the President as to render him ineffective in conducting foreign relations. But there is no proof that any such approval of those terms which survive negotiation and which are intended as permanent and binding would import that same effect. The Department of State, for example, was able to extract major concessions from other countries at The Hague in 1955 even though the agreed revision could not become effective in the United States until the Senate approved. Similarly, while it is true that the threat to denounce a treaty is an important negotiation tactic, the requirement of Senate consent should not reduce its effectiveness. On the contrary, had the Executive before going to Montreal first obtained legislative assent to termination of the Warsaw Convention, ${ }^{157}$ the display of national unity may have gained results equally as impressive-though perhaps less hasty and arbitrary-while at the same time assuring better representation of affected interests by public airing of the issues. When presented to the Legislature, executive proposals for new treaties or for their termina-

156 Pound, Introduction to Levirt, The President and the InTernational Affairs of THE UNITED STATES at vi (1954).

157 Earlier at The Hague, when the United States had difficulty obtaining its goal of $\$ 25,000$ liability limits, "the United States delegation 'banged its fists on the table; [and] talked of possible denunciation," Lowenfeld \& Mendelsohn, supra note 129, at 506-07. When the delegation went to Montreal in 1966, this time after having tendered presidential denunciation, again many delegates from other nations "failed to grasp the fact that the United States was really serious. Many of the delegates thought the denunciation was a bluff, and that the $\$ 100,000$ figure was simply an opening for a horse-trading session. When the United States did not quickly reduce its demands, as it had done at The Hague, some delegates thought the United States did not really want agreement at all and was merely seeking an alibi for unilateral action." Id. at 564.

Just prior to executive denunciation, there was a noted temper in Congress of dissatisfaction with United States membership in the Warsaw convention, see note 27 supra, which the President could have employed to denounce the Convention more impressively in the eyes of other nations and, perhaps, obtain improved terms by direct amendment to the Warsaw Convention at Montreal. 
tion or amendment have seldom been unduly delayed or dismissed unless of a distinctly controversial nature, ${ }^{158}$ in which case the legitimate function of that branch is to brake hasty action until the controversy is resolved. But this history of Senate cooperation should not be mistaken for subservience. The constitutional requirement of legislative approval has provided a permanent opportunity to examine executive proposals before binding private interests by law.

As for the Warsaw Convention changes, the Congress may yet play a positive role by demanding that the President submit the "interim arrangement" to open debate in the form of a treaty protocol before becoming permanent law. ${ }^{159}$ A subservient course would be dangerous, for, while independent executive action may not legally divest Congress of its powers unless sanctioned by long-continued acquiescence, congressional inaction tends to encourage the executive to act unilaterally. ${ }^{160}$ As Mr. Justice Jackson noted:

158 It was calculated that until 1945 only seven to ten treaties had been directly vetoed by the Senate, the most notable being the Versailles Peace Treaty, which would have organized the League of Nations. Some 20 per cent were abandoned by the President because of unacceptable Senate amendments or legislative inaction. See Borchard, Treaties and Executive Agreements-A Reply, 54 YALE L.J. 616, 657 (1945); Wright, The United States and International Agreements, 38 AM. J. INT'L L. 341, 353 (1945).

159 The Administration itself has promised to submit the arrangement to the Senate at some future date. Mr. Leonard K. Meeker, Legal Advisor for the Department of State, in the Dep't of State Letter, supra note 124, at 246, said: "[I]t should be emphasized that the arrangement . . . will be in effect for an interim period only. It will be the subject of a diplomatic conference at some future date, at which time appropriate modifications to the arrangement can be made. Prior to the conference, all interested parties will be invited to present their views on all aspects of the issue. If the diplomatic conference reaches agreement on a new convention, that convention will be submitted for the advice and consent of the Senate, at which time public hearings will again be held."

160 With his initiative in the field of foreign affairs, the President "is consequently able to confront the other departments, and Congress in particular, with faits accomplis at will, although, on the other hand, Congress is under no constitutional obligation to back up such faits accomplis or to support the policies giving rise to them." Corwin, op. cit. supra note 131 , at 180.

Congress in the past has exerted its prerogative to re-examine executive arrangements which it deemed proper subjects for treaties, and in several cases revised or terminated such arrangements. Through the Secretary of State, the President repeatedly justified the conclusion of the Chicago Air Transport Agreements (often referred to as the "Two Freedoms" and "Five Freedoms" agreements) without reference to the Senate. See Letter by Acting Secretary of State Grew to Senator Bilbo of the Senate Committee on Foreign Relations, June 9, 1945, in 7 Documents on American Foreign Relations 622 (Goodrich \& Carroll eds. 1945). Nonetheless, lively criticism of the action by the Senate led to denunciation of the agreements by the United States in 1946. See Lissitzyn, The Legal Status of Executive Agreements on Air Transportation, 17 J. ATR. L. \& CoM. 436, 443 (1950). Part of the controversy centered upon the complaint that, while bilateral executive agreements have been entered into for temporary purposes as modus vivendi, multilateral agreements should be incorporated into treaty form, particularly where they purport to change prior legislative enactments. Borchard, supra note 158, at 642-43 (1945). 
I have no illusion that any decision by this Court can keep power in the hands of Congress if it is not wise and timely in meeting its problems. A crisis that challenges the President equally, or perhaps primarily, challenges Congress. If not good law, there is worldly wisdom in the maxim attributed to Napoleon that "The tools belong to the man who can use them." We may say that power to legislate for emergencies belongs in the hands of Congress, but only Congress itself can prevent power from slipping through its fingers. ${ }^{161}$

\section{CONCLUSION}

The "Montreal Agreement," signed by private beneficiaries of the Warsaw Convention as a means of preventing denunciation of that treaty by the President of the United States, represents a new approach to executive legislation by treaty. Neither the Constitution nor the courts have indicated that the President has authority to terminate a binding, viable treaty obligation without the consent of Congress or the Senate. When exercise of the termination power to reconstruct major treaty provisions affects private rights and the regulation of domestic and foreign commerce, legislative sanction should be required. Absent special factors requiring speed and secrecy to amend or revoke a treaty, the need for full debate and representation of affected interests demands congressional consideration. The Warsaw Conven-

The proposed treaty regulating administration of the oil industry was submitted to the Senate for approval only after members of the Foreign Relations Committee decided that the previously concluded Oil Agreement of August 8, 1944, with Great Britain, was a proper subject for treaty alone. Id. at 634-35. Finally, the Aiken "St. Lawrence Waterway" Bill embodied an independent executive agreement with practically the same commitments with Canada which the Senate had rejected as a treaty proposal on March 14, 1934, by a 46-42 vote. The Commerce Committee, however, resisted the effort to pass a rejected treaty provision in the form of Joint Resolution, and the Senate defeated the bill on December 12,1944 , by a vote of 25-56. Id. at 619, 653-55.

161 Youngstown Sheet \& Tube Co. v. Sawyer, 343 U.S. 579, 654 (1952) (Jackson, J., concurring). Professor Kurland similarly views the challenge to Congress: "In the course of this century, the states have surrendered their role as meaningful components in our system of government by failing to recognize that the necessary concomitant of power is responsibility. In the words of Patrick Henry, Congress may profit from their example. Seven hundred and fifty years ago, at Runnymede, began a chain of events that eventually resulted in the supremacy of Iegislative over executive power in Anglo-American government. Somewhere in the recent past, perhaps with the Great Depression, perhaps at Pearl Harbor, perhaps at Los Alamos, the United States crossed the watershed and started moving toward a restoration of the supremacy of the executive power. How far we have traveled is hard to say. The success or failure of presidential price and wage controls [or, perhaps, legislation by treaty] may give us some basis for judgment." Kurland, Guidelines and the Constitution: Some Random Observations on Presidential Power to Control Prices and Wages, in Guidelines, Informal Controls and the Market Place 240 (Shultz and Aliber eds. 1966). 
tion is a commercial treaty directed primarily toward private interests and thus should not have been denounced or revised without approval by Congress or the Senate. In circumventing that procedure, the President exceeded the authority of his office. 